\title{
Zooplankton (Copepoda, Rotifera, Cladocera and Protozoa: Amoeba Testacea) from natural lakes of the middle Rio Doce basin, Minas Gerais, Brazil
}

\section{Paulina M. Maia-Barbosa ${ }^{1,3}$, Rosa Maria Menendez, Diego Guimarães Florencio Pujoni, Sofia Luisa Brito ${ }^{2}$, Akemi Aoki', Francisco Antônio Rodrigues Barbosa ${ }^{1}$}

${ }^{1}$ Universidade Federal de Minas Gerais, Instituto de Ciências Biológicas, Laboratório de Limnologia, Ecotoxicologia e Ecologia Aquática. Av. Antônio Carlos, 6627. CEP. 31270-901, Belo Horizonte, MG, Brasil. http://www.big.icb.ufmg.br/

${ }^{2}$ UNESCO-HidroEx, Av. Mário Palmério, 1000 - Bairro Universitário - Frutal, MG, Brasil. http:// www.hidroex.mg.gov.br/

${ }^{3}$ Corresponding author.E-mail: maia@icb.ufmg.br

BARBOSA, P.M.M., MENENDEZ, R.M., PUJONI, D.G.F., AOKI, A., BARBOSA, A.R. Zooplankton (Copepoda, Rotifera, Cladocera and Protozoa: Amoeba Testacea) from natural lakes of the middle Rio Doce basin, Minas Gerais, Brazil. Biota Neotropica. 14(1): e20134040. http://www.biotaneotropica.org.br/v14n1/en/abstract?inventory+bn00414012014

\begin{abstract}
A list of zooplankton species identified during ten years of studies in the lake system of the middle Rio Doce basin is presented. This lake system integrates the Atlantic Forest biome, a biodiversity hotspot. Three types of studies were achieved by the Brazilian Long Term Ecological Research Program (Brasil-LTER/PELD-UFMG site 4): i) a temporal study (study 1) which sampled four lakes monthly and three lakes twice a year during ten years; ii) a comparative study of limnetic and littoral species composition (study 2) and iii) a spatial study (study 3 ) that evaluated the species composition of eighteen lakes (eight lakes inside the Rio Doce State Park (RDSP) and ten lakes in its surrounding area) during one year with quarterly sampling. A total of 354 taxa were identified out of which 175 belong to the Rotifera, 95 to the Protozoa (Amoeba Testacea), 55 to Cladocera and 25 to Copepoda. Although many identified species where common in tropical environments, we present new records for the Middle Rio Doce basin. The group of lakes outside the RDSP showed higher exclusive species compared to lakes inside the RDSP. This pattern may be due to higher disturbance intensity and frequency to which the lakes outside RDSP are subjected, being an important factor affecting community structure. These aquatic ecosystems presents more than half of the zooplankton species registered for the Minas Gerais State and is, undoubtedly, one of the Brazil's priorities for conservation, sustaining high diversity in a very small, limited and threatened region.
\end{abstract}

Keywords: Species list, Atlantic Forest, Freshwater.

BARBOSA, P.M.M., MENENDEZ, R.M., PUJONI, D.G.F., AOKI, A., BARBOSA, A.R. Zooplâncton (Copepoda, Rotifera, Cladocera and Protozoa: Amoeba Testacea) de lagos naturais do trecho médio da bacia do Rio Doce, Minas Gerais, Brasil. Biota Neotropica. 14(1): e20134040. http://www.biotaneotropica.org.br/v14n1/pt/abstract?inventory+bn00414012014

Resumo: Uma lista das espécies de zooplâncton identificadas durante dez anos de estudos no sistema de lagos do médio Rio Doce é apresentada. Este sistema de lagos faz parte do bioma da Mata Atlântica, um hotspot de biodiversidade. Três tipos de estudos foram conduzidos pelo Programa de Pesquisas Ecológicas de Longa Duração (PELD-UFMG site4): i) um estudo temporal, que amostrou quatro lagoas mensalmente e três lagoas semestralmente durante dez anos; ii) um estudo comparativo entre a composição de espécies da região limnética e litorânea e iii) um estudo espacial que avaliou a composição de espécies de dezoito lagoas (oito dentro dos limites do Parque Estadual do Rio Doce (PERD) e dez na sua região do entorno) durante um ano com amostragens trimestrais. Um total de 354 taxa foram identificados sendo 175 pertencentes a Rotifera, 95 a Protozoa (Amoeba Testacea), 55 a Cladocera e 25 a Copepoda. Embora muitas espécies identificadas sejam comuns a ambientes tropicais, são apresentados novos registros para a bacia do Médio Rio Doce. O grupo de lagos fora do PERD apresentou uma maior riqueza exclusiva comparado ao grupo de lagoas dentro do PERD. Este padrão pode ser devido a maiores frequência e intensidade de distúrbios aos quais as lagoas fora do PERD estão sujeitas, já que este é um fator importante que afeta a estruturação de comunidades. Este ecossistema aquático apresenta mais da metade das espécies de zooplâncton já registradas para o Estado de Minas Gerais e é, sem dúvida, uma das prioridades do Brasil para a conservação, sustentando uma alta diversidade em uma região muito pequena, limitada e ameaçada.

Palavras-chave: Lista de espécies, Mata Altântica, Água Doce. 


\section{Introduction}

Brazil is known as the most mega diverse country (Myers et al. 2000). The Atlantic Forest is classified as a biodiversity hotspot, as it is one of the most deforested and threatened amongst the Brazilian biomes that still maintains a high species diversity (Fonseca 1985, Mittermeier et al. 1998). Furthermore, inland waters have become critical ecosystems for conservation, since they bear a high biodiversity in confined spaces, threatened by humanity's need for water (Dudgeon et al. 2006). The middle Rio Doce lake system is a lacustrine complex formed by c. 300 natural water bodies amidst the Atlantic Forest biome. Considering its regional importance, in 1944, a state decree created the Rio Doce State Park (RDSP) which is the largest continuous Atlantic Forest fragment in Minas Gerais state, recently incorporated to the Ramsar sites for preservation of wetlands (RAMSAR 2010)

Despite having its integrity protected by law, Gontijo \& Britto (1997) identified 26 types of human impacts occurring both internally and externally to the Park's boundaries. Among the impacts within the park the illegal hunting and fishing, introduction of exotic species (mollusks, fishes and even a primate) and tourism on the shore grounds of Lake Dom Helvécio deserve special attention. Concerning the latter, some modifications in the species abundance and functioning were related to anthropic interferences (Maia-Barbosa et al. 2010). Some examples of impacts in the vicinity of the Park, which have been cited by the authors, are the extensive Eucalyptus spp. monocrops - mainly used as charcoal in the steel plants - the extensive farming and abandoned pasture lands, and a fast growing urbanization that produces sewage and garbage which, not rarely, reaches the Park limits.

Since the 1970 's, the plankton diversity of this lake system has been cataloged (e.g. Barbosa \& Tundisi 1980). After the implementation of the LTER program in November 1999 (LTER/PELD-UFMG site 4), samplings became systematic until late 2010. The Brazilian site 4 ILTER project aims to evaluate the impacts of anthropogenic activity on local and regional biodiversity assuming that the RDSP has been threatened mainly by two factors: forest fragmentation and introduction of exotic species.

With the objective to catalog the existing zooplankton biodiversity of the middle Rio Doce lake system, we present in this study the limnologic features and the species list of the zooplankton community of eighteen lakes (eight inside the RDSP and ten in its surrounding). The objective was assessed with three interrelated studies conducted in site 4 by the ILTER/PELD program:

Study 1: Long term (1999-2009) monitoring of limnological variables and plankton community in the limnetic region of seven lakes;

Study 2: Plankton studies conducted in the littoral zone of two lakes with samplings during rainy and dry periods;

Study 3: Large spatial scale monitoring of limnological variables and plankton community in the limnetic region of eighteen lakes with quarterly samplings during one year.

\section{Material and Methods}

\section{Study site}

The naturally barred lake system is located in the middle part of the Rio Doce basin (19²9'24" S $\left.19^{\circ} 48^{\prime} 18^{\prime \prime} \mathrm{S}, 42^{\circ} 28^{\prime} 18^{\prime \prime} \mathrm{W}-42^{\circ} 38^{\prime} 30^{\prime \prime} \mathrm{W}\right)$ and was formed by tectonic and sedimentary mechanisms during late Pleistocene (Mello et al. 1999) (Figure 1). The region has a marked seasonality exhibiting two distinct periods: the dry period (May-August), with low temperature and precipitation and the rainy period (September to April), with high values of temperature and precipitation, allowing to classify the region as tropical semi-humid with mesothermal characteristics (Tundisi 1997). The lakes within the RDSP are currently protected from recent human impacts, despite still suffering with past impacts such as the introduction of exotic fish species (Latini \& Petrere 2004). Most lakes outside the park had their surrounding natural forests replaced by Eucalyptus spp. plantations and some lakes are used for recreation, fishing clubs and local projects for net cage fish cultures (e.g. Jacaré and Verde lakes).

\section{Data Collection and Analysis}

The zooplankton community was sampled at a fixed point in the pelagic zone filtering 200 liters of lake water through a $68 \mu \mathrm{m}$ plankton net using a hydraulic pump at depths defined by the Secchi disk assumed as corresponding to $10 \%$ of incident light (Cole, 1983). In shallow lakes (depth $<3 \mathrm{~m}$ ) samples were collected at the sub-surface, at the Secchi depth and at $0.5 \mathrm{~m}$ from the bottom. For the study in the littoral region of Patos lake ten liters of water were filtered through a $45 \mu \mathrm{m}$ plankton net with a bucket. Different macrophyte banks were evaluated and six samples were collected two meters distant from each other along a transect parallel to the lake's margin (Table 1). The littoral region of Dom Helvécio lake was also sampled and the results presented by Maia-Barbosa et al. (2008). All collected samples were immediately transferred into plastic bottles, stained with rose bengal and preserved with $4 \%$ neutral formaldehyde solution. The identification of the species was made under a light microscope at $200 \mathrm{x}$ to $1000 \mathrm{x}$ magnification, referring to the relevant taxonomic literature (e.g. Koste 1978, Koste \& Robertson 1983, Reid 1985, MatsumuraTundisi 1986, Dussart 1987, Segers 1995, Segers \& Dumont 1995, Smirnov 1996, Elmoor-Loureiro 1997, Rocha 1998, Gomes-Souza 2008, checked for synonyms and redescriptions)

Water temperature, dissolved oxygen and $\mathrm{pH}$ were measured each time with a multiprobe Horiba U-22 sensor. Water samples were also collected for total phosphorus quantification, according to Mackereth et al. (1978). The samplings were authorized by the Minas Gerais State Forest Institute (IEF-MG, license number 005/07).

Using data from study 3 , where the sample effort was the same for all 18 lakes (4 months and 3 depths $=12$ samples), we calculated the $95 \%$ percentile confidence interval for the medians of total phosphorus by nonparametric bootstrap with 10000 replications (Efron 
\& Tibshirani 1993). Sample-Based Rarefaction Curves were also constructed with biological data from study 3 using the exact calculations of the average and standard deviation of species richness for combinations of samples (Gotelli \& Cowell 2001)

The zooplankton samples are stored in the Laboratório de Limnologia, Ecotoxicologia e Ecologia Aquática of the Instituto de Ciências Biológicas of the Universidade Federal de Minas Gerais, Brazil.

\section{Results and discussion}

The sampled lakes in this study are listed in Table 2 with geographic coordinates and some lake characteristics. The identified species list is presented in Table 3. Concerning the data from study 3 and according to trophic index limits based on total phosphorus concentration proposed by Lamparelli (2004), the majority of the lakes were classified as mesotrophic although some exhibit tendency to eutrophy such as lakes Pimenta, Santa Helena, Barra,

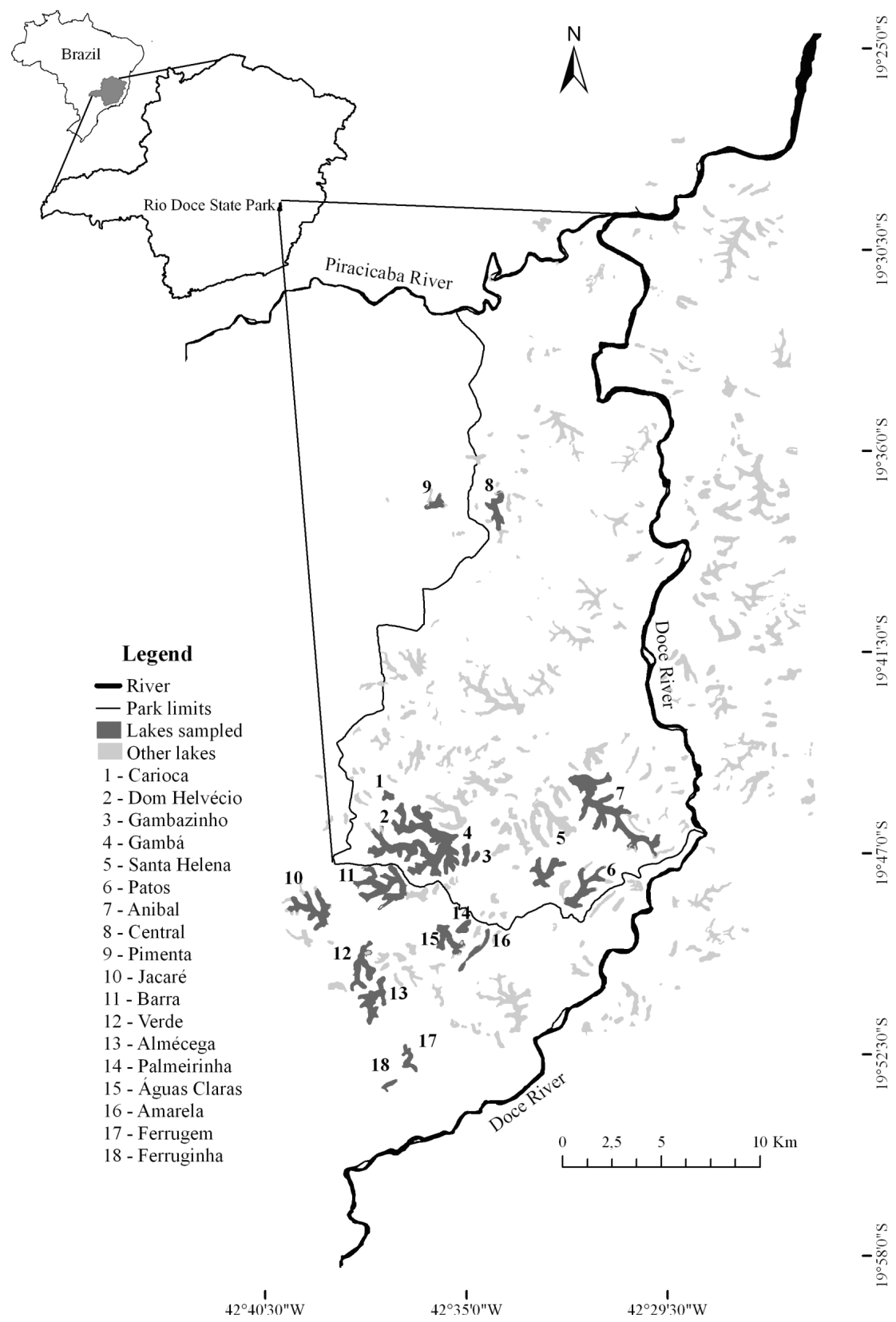

Figure 1: The lake system of the middle Rio Doce basin. The sampled lakes are shaded. 
Barbosa, P.M.M.. et al.

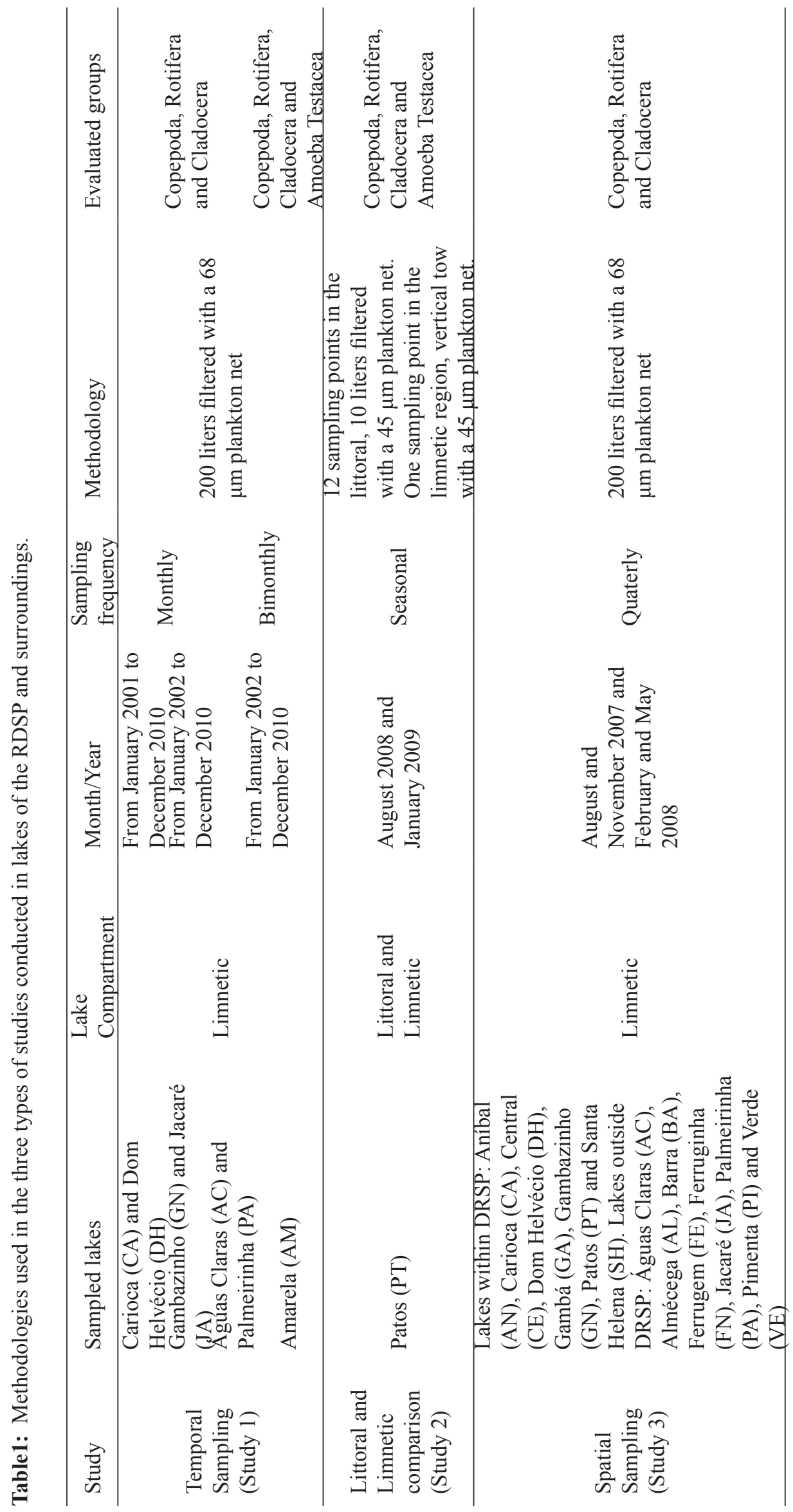


Table 2: Lakes' initials, names, geographic coordinates of sampling points, altitude, lakes' area, margin development index (DL), mean depth at the sampling point in the four periods sampled in study 3 (August and November 2007 and February and May 2008) and lake location in relation to Rio Doce State Park boundaries.

\begin{tabular}{|c|c|c|c|c|c|c|c|}
\hline Lake initials & Lake name & $\begin{array}{l}\text { Sampling point } \\
\text { coordinates }\end{array}$ & $\begin{array}{l}\text { Sampling } \\
\text { point } \\
\text { altitude } \\
(\mathrm{m})\end{array}$ & $\begin{array}{l}\text { Lake } \\
\text { area } \\
\left(\mathrm{Km}^{2}\right)\end{array}$ & $\mathrm{DL}$ & $\begin{array}{l}\text { Mean depth at } \\
\text { the sampling } \\
\text { point } \\
\text { (m) }\end{array}$ & $\begin{array}{l}\text { Location } \\
\text { according to } \\
\text { RDSP limits }\end{array}$ \\
\hline $\mathrm{AC}$ & Águas Claras & $\begin{array}{c}\mathrm{S} 19^{\circ} 49^{\prime} 06,9^{\prime \prime} \\
\text { W } 042^{\circ} 35^{\prime} 42,5^{\prime \prime}\end{array}$ & 254 & 0.62 & 2.24 & 9.1 & Outside \\
\hline $\mathrm{AL}$ & Almécega & $\begin{array}{c}\text { S } 19^{\circ} 51^{\prime} 25,4^{\prime \prime} \\
\text { W } 042^{\circ} 37^{\prime} 31,9^{\prime \prime}\end{array}$ & 268 & 0.92 & 2.44 & 6.4 & Outside \\
\hline $\mathrm{AM}$ & Amarela & $\begin{array}{c}\text { S } 19^{\circ} 49^{\prime} 23,1^{\prime \prime} \\
\text { W } 042^{\circ} 34^{\prime} 28,7^{\prime \prime}\end{array}$ & 250 & 0.20 & 1.82 & 1.9 & Outside \\
\hline AN & Aníbal & $\begin{array}{c}\text { S } 19^{\circ} 46^{\prime} 47,1^{\prime \prime} \\
\text { W } 042^{\circ} 29^{\prime} 54,5^{\prime \prime}\end{array}$ & 237 & 2.75 & 4.29 & 5.1 & Inside \\
\hline BA & Barra & $\begin{array}{c}\mathrm{S} 19^{\circ} 48^{\prime} 11,1^{\prime \prime} \\
\mathrm{W} 042^{\circ} 37^{\prime} 43,6^{\prime \prime}\end{array}$ & 249 & 1.12 & 3.45 & 6.4 & Outside \\
\hline CA & Carioca & $\begin{array}{c}\text { S } 19^{\circ} 45^{\prime} 26,0^{\prime \prime} \\
\text { W } 042^{\circ} 37^{\prime} 06,2^{\prime \prime}\end{array}$ & 270 & 0.12 & 1.28 & 9.4 & Inside \\
\hline $\mathrm{CE}$ & Central & $\begin{array}{c}\mathrm{S} 19^{\circ} 37^{\prime} 39,0^{\prime \prime} \\
\text { W } 042^{\circ} 34^{\prime} 12,5^{\prime \prime}\end{array}$ & 264 & 0.51 & 2.03 & 4.5 & Inside \\
\hline DH & Dom Helvécio & $\begin{array}{c}\text { S } 19^{\circ} 46^{\prime} 55,7^{\prime \prime} \\
\text { W } 042^{\circ} 35^{\prime} 28,9^{\prime \prime}\end{array}$ & 257 & 3.81 & 4.93 & 27.5 & Inside \\
\hline $\mathrm{FE}$ & Ferrugem & $\begin{array}{c}\text { S } 19^{\circ} 52^{\prime} 39,0^{\prime \prime} \\
\text { W } 042^{\circ} 36^{\prime} 34,3^{\prime \prime}\end{array}$ & 270 & 0.34 & 2.01 & 3.3 & Outside \\
\hline FN & Ferruginha & $\begin{array}{c}\text { S } 19^{\circ} 53^{\prime} 17,5^{\prime \prime} \\
\text { W } 042^{\circ} 36^{\prime} 59,4^{\prime \prime}\end{array}$ & 273 & 0.13 & 1.61 & 3.9 & Outside \\
\hline GA & Gambá & $\begin{array}{c}\text { S } 19^{\circ} 47^{\prime} 15,1^{\prime \prime} \\
\text { W } 042^{\circ} 35^{\prime} 01,0^{\prime \prime}\end{array}$ & 209 & 0.23 & 1.40 & 11.0 & Inside \\
\hline GN & Gambazinho & $\begin{array}{c}\text { S } 19^{\circ} 47^{\prime} 07,7^{\prime \prime} \\
\text { W } 042^{\circ} 34^{\prime} 45,5^{\prime \prime}\end{array}$ & 260 & 0.09 & 1.13 & 9.3 & Inside \\
\hline JA & Jacaré & $\begin{array}{c}\mathrm{S} 19^{\circ} 48^{\prime} 37,8^{\prime \prime} \\
\mathrm{W} 042^{\circ} 38^{\prime} 57,0^{\prime \prime}\end{array}$ & 269 & 1.05 & 2.90 & 7.6 & Outside \\
\hline PA & Palmeirinha & $\begin{array}{c}\mathrm{S} 19^{\circ} 49^{\prime} 41,8^{\prime \prime} \\
\mathrm{W} 042^{\circ} 36^{\prime} 25,4^{\prime \prime}\end{array}$ & 271 & 0.20 & 1.28 & 5.6 & Outside \\
\hline PI & Pimenta & $\begin{array}{c}\text { S } 19^{\circ} 37^{\prime} 27,4^{\prime \prime} \\
\text { W } 042^{\circ} 35^{\prime} 44,3^{\prime \prime}\end{array}$ & 263 & 0.22 & 1.63 & 3.1 & Outside \\
\hline PT & Patos & $\begin{array}{c}\mathrm{S} 19^{\circ} 48^{\prime} 19,9^{\prime \prime} \\
\text { W } 042^{\circ} 32^{\prime} 12,7^{\prime \prime}\end{array}$ & 257 & 0.86 & 2.83 & 7.3 & Within \\
\hline SH & Santa Helena & $\begin{array}{c}\mathrm{S} 19^{\circ} 47^{\prime} 48,8^{\prime \prime} \\
\mathrm{W} 042^{\circ} 33^{\prime} 04,7^{\prime \prime}\end{array}$ & 262 & 0.68 & 2.42 & 9.0 & Inside \\
\hline VE & Verde & $\begin{array}{c}\mathrm{S} 19^{\circ} 49^{\prime} 55,2^{\prime \prime} \\
\mathrm{W} 042^{\circ} 37^{\prime} 54,1^{\prime \prime}\end{array}$ & 274 & 0.75 & 2.29 & 11.3 & Outside \\
\hline
\end{tabular}




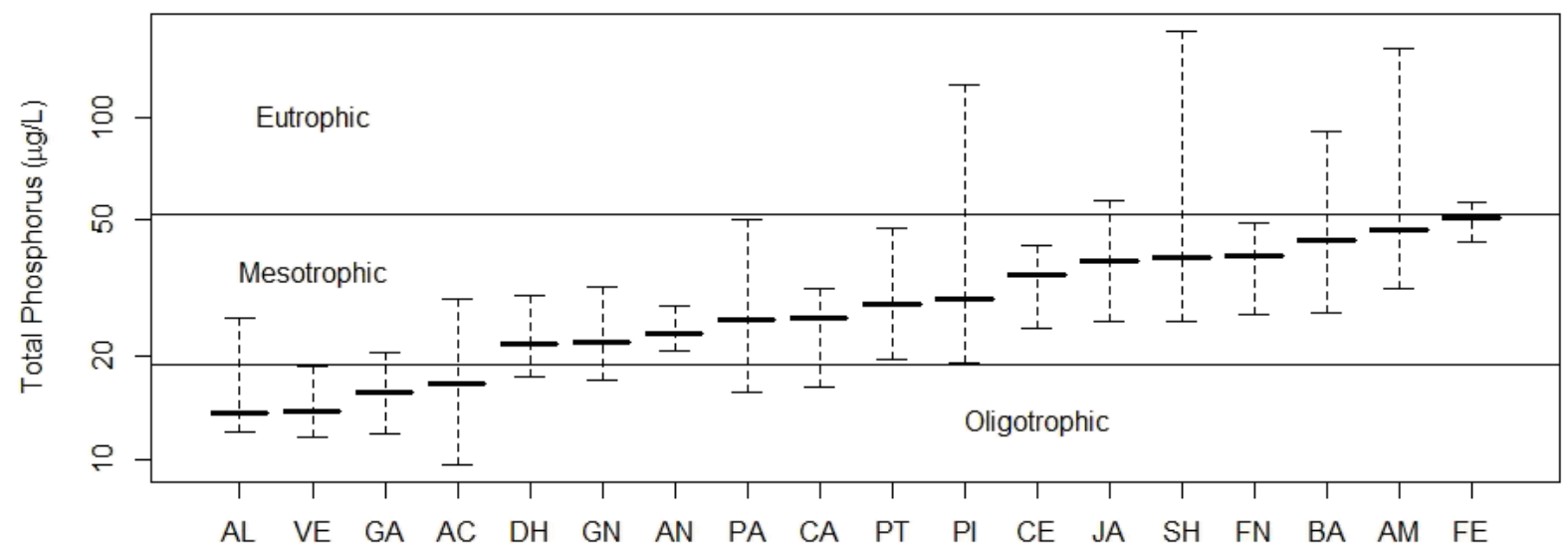

Figure 2: Median and 95\% percentilic interval (whiskers) of the total phosphorus concentration median in the 18 lakes.

Amarela and Ferrugem (Figure 2). Only lake Verde was considered strictly oligotrophic. Water temperature has an amplitude of $10^{\circ} \mathrm{C}$ between dry and rainy periods (from $22^{\circ} \mathrm{C}$ to $32^{\circ} \mathrm{C}$, respectively), dissolved oxygen concentrations showed a mean of $5.8 \mathrm{mg} / \mathrm{L}$, varying from $9.4 \mathrm{mg} / \mathrm{L}$ in the sub-surface to complete anoxia at some depths greater than five meters and $\mathrm{pH}$ varied between 8.6 and 5. The lakes' area varied from 0.09 to $3.81 \mathrm{Km}^{2}$ with a mean of $0.81 \mathrm{Km}^{2}$ (Table 2).

In a large sample effort Tundisi \& Saijo (1997) evaluated the zooplankton biodiversity of 13 lakes of this system in November 1985 and July 1987. The authors reported 16 species of Rotifera, 9 of Cladocera and 7 of Copepoda. Moreto (2001) evaluated the limnetic and littoral region of 5 lakes of this system and identified 39 species of Rotifera, 13 of Cladocera and 4 of Copepoda. Considering the three studies described in our study, a total of 354 zooplankton species were identified out of which 175 belonging to Rotifera, 55 to Cladocera, 25 to Copepoda and 95 to Protozooa (Amoeba Testacea) (Table 3). The species Itura aurita (Ehrenberg, 1830), Ploesoma truncatum (Levander, 1894), Biapertura affinis (Alona ossiani Sinev, 1998) and Brachionus caudatus Barrois \& Daday, 1894 were reported only by Moreto (2001). Argyrodiaptomus furcatus (Sars, 1901) and Scolodiaptomus corderoi Wright, 1936 were recorded in lake Dom Helvécio in the 80's by Tundisi \& Saijo (1997), but these species have never been reported since that time, being considered locally extinct, probably due to nonnative fish species introduction (Pinto-Coelho et al. 2008). The other species cited only by Tundisi \& Saijo (1997) and Moreto (2001) are considered synonyms, redescriptions or misidentifications as described hereafter. Mesocyclops brasilianus Kiefer, 1933 may be M. meridianus (Silva \& Matsumura-Tundisi 2011) as both species are restricted to the southern hemisphere, despite the latter having a wider distribution (Silva 2008), Conochiloides caenobasis Skorikov, 1914 was redescribed as C. (Conochiloides) coenobasis (Skorikov, 1914), Monostyla bulla Gosse, 1851 as Lecane bulla (Gosse, 1851) and Brachionus patulus Müller, 1786 as Plationus patulus (Müller, 1786). Disparalona sp. may be Disparalona dadayi redescribed as Alonella dadayi Birge, 1910, Macrothrix laticornis (Jurine, 1820) may be Macrothrix squamosa Sars, 1901, a Neotropical species and Keratella quadrata may be K. tropica as both are cosmopolitan species although the former is restricted to cold climates (Segers \& Smet 2008). The species Synchaeta stylata was cited by Moreto (2001) but in our study the individual was identified only until genus level. Lecane gillardi armata Koste, 1978 is a synonym for Lecane armata and Proales giganthea (Glascott, 1893) is probably a misidentification because this specie is not recorded in Neotropical regions. Alona quadrata is not a valid species so its report is considered as uncertain.

The checklist presented by the Project BIOTA/FAPESP in São Paulo state reported 277 Rotifera species from 90 water bodies, 12 Copepoda Calanoida species from 250 water bodies, 39 species of Copepoda Cyclopoida from 207 water bodies and 96 Cladocera species from 300 water bodies (Matsumura-Tundisi \& Tundisi 2011, Silva \& Matsumura-Tundisi 2011, Rocha et al 2011, Soares et al. 2011). In the upper Paraná River flood plain 541 species were reported from 36 aquatic environments from 2000 to 2007 (Lansac-Tôha,et al. 2009). Comparing the richness here reported we can see that the middle Rio Doce sustains high zooplankton diversity in a very small and limited region.

The dominance of rotifer species is a common pattern in most of the cited environments and can be explained by its typical opportunistic life history with parthenogenetic reproduction and short life cycles combined with the ability to produce eggs that survive desiccation, resulting in great resistance and resilience to disturbances (Allan 1976). Within the rotifers, four families contributed significantly to the species richness: Lecanidae, with 43 species of the genus Lecane, Brachionidae, with 22 species ( 8 species of Brachionus), Lepadellidae, with 21 species (14 Lepadella species) and Trichocercidae, with 17 Trichocerca species. Moreto (2001) also reported 
Lecanidae and Brachionidae as the families with the largest number of species, although there was great contribution of other species. The following species were widespread, occurring in at least 15 of the 18 sampled lakes: Anuraeopsis spp. Brachionus angularis Gosse, 1851, B. falcatus Zacharias, 1898, B. mirus Daday, 1905, Keratella americana Carlin, 1943, Lecane bulla (Gosse, 1851), L. lunaris (Ehrenberg, 1832), Trichocerca pusilla (Jennings, 1903), Hexarthra intermedia (Wiszniewski, 1929), Conochilus spp., Ptygura libera Myers, 1934 and bdelloid rotifers. Most of these species are known to be cosmopolitan, and the association of Lecane, Brachionus, Keratella and Trichocerca is regarded as typical in tropical regions as well as the dominance of Brachionidae and Lecanidae families reported by other authors (Paggi \& José de Paggi 1990, Bozelli 1992, Sendacz 1993, Bonecker et al. 1994, Lansac-Toha et al. 1997).

Bosmina tubicen Brehm, 1953 and Diaphanosoma birgei Korineck, 1981 were the most common cladoceran species found in fifteen and fourteen lakes respectively. Among the copepods, Thermocyclops minutus (Lowndes, 1934) was present in all eighteen lakes and Notodiaptomus isabelae (Wright S., 1936) wasn't recorded only in three lakes (Amarela, Pimenta and Santa Helena). The occurrence of two exotic species should also be noted: Kellicottia bostoniensis (Rousselet, 1908) (Rotifera) and Mesocyclops ogunnus Onabamiro, 1957 (Copepoda), but these species were recorded only once and may not have established themselves.

The protozoan group was represented by 95 Testacea species and 4 ciliates species, although no specific sampling procedure was employed. The recorded species were collected in littoral zones of two lakes (Dom Helvécio and Patos) and in Amarela lake. Difflugidae, with 39 species (26 Difflugia species) and Arcellidae, with 22 species (15 Arcela species) were the families with the highest richness. Compared with the checklist provided by Regali-Seleghim et al. (2011), where 84 taxa of Testacea were reported from 75 aquatic environments in São Paulo state, the richness reported in our work is very expressive and it might be underestimated because only three lakes were evaluated. Lake Amarela alone had a richness of 74 species, with predominance of Difflugia (21 species), Arcella (15 species) and Centropyxis (13 species). The families of these three genera are described as dominant in littoral environments.

Considering the results from study 3 , where the 18 lakes were sampled with the same effort, from a total of 95 identified taxa, 29 taxa were recorded only in lakes outside the park limits and 7 taxa were recorded only in lakes inside the park limits. This greater richness of the group of lakes outside the park can be clearly visualized with Sample-Based Rarefaction Curves plot (Figure 3). Most of the exclusive richness found in lakes outside the park is due to Amarela lake, which is small and shallow (area $<30$ ha and depth $<3 \mathrm{~m}$ ) with a well-developed macrophyte community. But even if we remove Amarela lake from the outside group of lakes we can see that this group still has a higher richness compared to lakes inside the park (Figure 4). This pattern is probably due to higher disturbance intensity and frequency to which the lakes outside the park limits are subjected, thus preventing lakes to reach a stable state where competitive exclusion may take place.

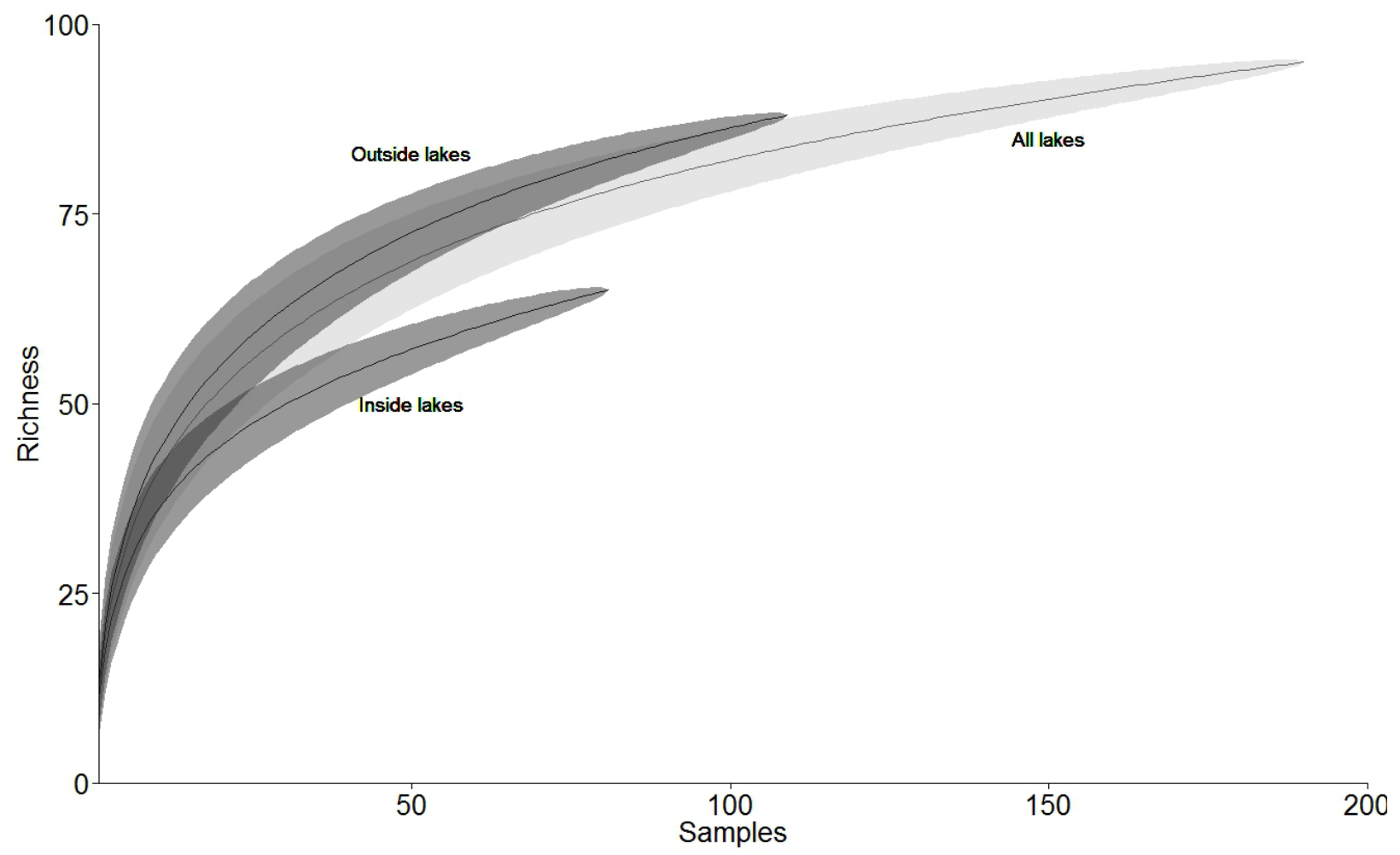

Figure3: Sample-Based rarefaction Curves with all the samples from study 3 (All lakes), and divided between lakes inside the 


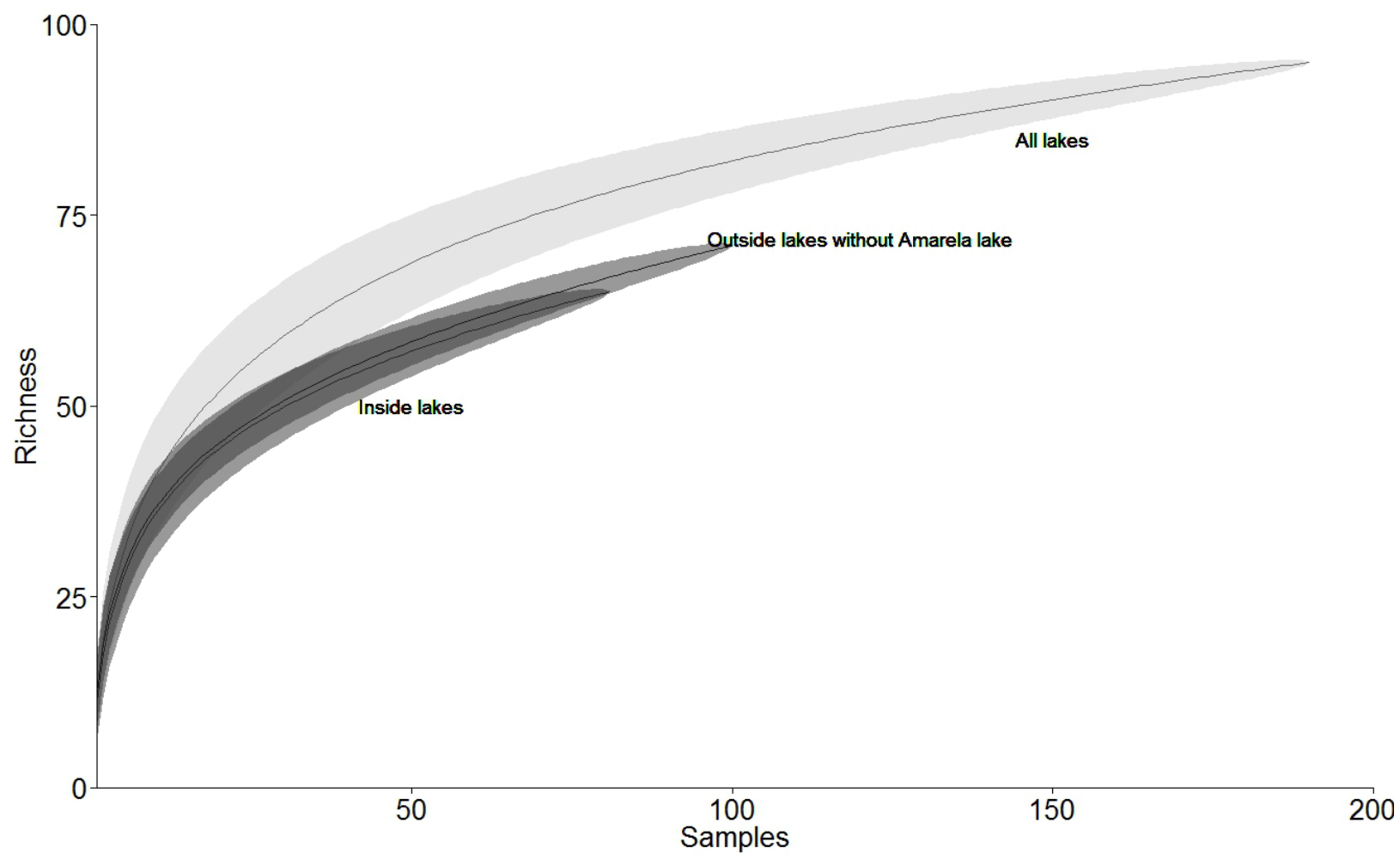

Figure4: Sample-Based rarefaction Curves with all the samples from study 3 (All lakes), and divided between lakes inside the RDSP (Inside lakes) and lakes outside the RDSP without Amarela lake (Outside lakes without Amarela lake).

Study 2, conducted in the littoral and limnetic regions of Patos lake included 41 new taxa to the previous species list for the region. The most representative group was Rotifera (21 species), followed by Amoeba Testacea (13 species), Cladocera (5 species) and Copepoda ( 2 species). The species Lepadella minoruoides Koste and Robertson, 1983, Ptygura furcillata (Kellicott, 1889) and Lecane eutarsa Harring and Myers, 1926 with previous records only in the Amazon Basin, were identified in the littoral region of Patos lake.

The comparison between different types of studies confirms the importance of long-term biodiversity studies. Regarding only the Copepoda, Cladocera and Rotifera species from the seven lakes sampled in study 1 (long-term monthly samples) and comparing them to the richness of the same seven lakes in study 3 (spatial sampling with quarterly samplings during one year), 77 species were common to both studies, 6 species were recorded only in study 3 and 127 species only in study 1 . The importance of littoral zones must also be pointed out, since all new records for the state of Minas Gerais were identified in samples collected in this region.

An incomplete survey on the zooplankton diversity reported 551 zooplankton species for Minas Gerais state, 151 Protozoa, 300 Rotifera, 68 Cladocera, 30 Copepoda and 2 of insect larvae (Eskinazi-Sant'Anna et al. 2005) and another recent study updated the Cladocera group up to 94 species (Santos-Wisniewski 2010). Although these data show a substantial richness, they may be underestimated owing to the lack of information from some major basins of the state, such as Jequitinhonha, Paranaíba, and Grande and from some groups, such as Protozoa. The data published on Brazil's freshwater zooplankton biodiversity accounts for 457 Rotifera species (34\% recorded in RDSP), 112 Cladocera species (49\% recorded in RDSP) and 196 Copepoda species (13\% recorded in RDSP) (Ismael et al. 1999). For the neotropical biogeographic region 682 Rotifera species $(25 \%$ recorded in RDSP) are reported, 186 Cladocera species (29\% recorded in RDSP) and 561 Copepoda species (4 \% recorded in RDSP) (Boxshall \& Defaye 2008, Forró et al. 2008, Segers 2008). The high richness of zooplankton species in RDSP lakes and surrounding region (less than $0.01 \%$ of Brazil's area) draws attention to regional as well as nationwide relevance of this system to aquatic biodiversity.

\section{Acknowledgements}

The authors thank the National Council for Scientific and Technological Development (CNPq-MCT) for financing the Long Term Ecological Research Program - Site 4 (Process 520031/98-9), The Brazilian Federal Agency for Support and Evaluation of Graduate Education (CAPES), Fundação de Amparo a Pesquisa de Minas Gerais (FAPEMIG), the Forestry Institute of Minas Gerais (IEF-MG) and colleagues from the Laboratório of Limnologia, Ecotoxicologia and Ecologia Aquática of ICB - UFMG (LIMNEA) who contributed with this work.

\section{References}

ALLAN, J.D. 1976. Life history patterns in zooplankton. Am. Nat. 110:165-176. 
BARBOSA, F.A.R.\& TUNDISI, J.G. 1980. Primary production of phytoplankton and environmental characteristics of a shallow quarternary lake at Eastern Brasil. Arch. Hydrobiol. 90(2):139-161.

BONECKER, C.C., LANSAC-TÔHA, F.A. \& STAUB, A. 1994. Qualitative study of rotifers in different environments of the High Paraná River flooplain (MS), Brazil. Revista Unimar 16:1-16.

BOXSHALL, G.A. \& DEFAYE, D. 2008. Global diversity of copepods (Crustacea: Copepoda) in freshwater. Hydrobiologia. 595:195-207

BOZELLI, R.L. 1992. Composition of the zooplankton community of Batata and Mussurá Lakes and of the Trombetas River, State of Pará, Brazil. Amazoniana 12(2): 239-261.

COLE, G.A. 1983. Textbook of Limnology. The C.V. Mosby Company, St. Louis

DUDGEON, D., ARTHINGTON, A.H., GESSNER, M.O., KAWABATA, Z., KNOWLER, D., LÉVÊQUE, C., NAIMAN, R.J., PRIEUR-RICHARD, A.H., SOTO, D. \& STIASSNY. M.L.J. 2006. Freshwater biodiversity: importance, threats, status, and conservation challenges. Biol. Rev. 81(2):163-182.

DUSSART, B.H. 1987. Sur quelques Mesocyclops (Crustacea, Copepoda) d'Amerique du Sud. Amazoniana 10:149-161.

EFRON, B. \& TIBSHIRANI, R. 1993. An Introduction to the Bootstrap. Chapman \& Hal. New York.

ELMOOR-LOUREIRO, L.M.A. 1997. Manual de Identificação de cladóceros límnicos do Brasil. Universa, Brasília.

ESKINAZI-SANT'ANNA, E.M., MAIA-BARBOSA, P.M., BRITO, S.L. \& RIETZLER, A.C. 2005. Zooplankton Biodiversity of Minas Gerais State: a Preliminary Synthesis of Present Knowledge. Acta Limnol. Brasil. 17(2):199-218.

FONSECA, G.A.B. 1985. The vanishing Brazilian Atlantic forest. Biol. Conserv. 34(1):17-34.

FORRÓ, L., KOROVCHINSKY, N.M., KOTOV, A.A. \& PETRUSEK, A. 2008. Global diversity of cladocerans (Cladocera; Crustacea) in freshwater. Hydrobiologia 595:177-184.

GOMES-SOUZA, M.B. 2008. Guia das Tecamebas Bacia do Rio Peruaçu - Minas Gerais: subsídio para a conservação e monitoramento da Bacia do Rio São Francisco. Editora UFMG, Belo Horizonte.

GONTIJO, B. M. \& BRITTO, C.Q. 1997. Identificação e classificação dos impactos ambientais no Parque Florestal Estadual do Rio Doce - MG. GEONOMOS. 5(2):43-48.

GOTELLI, N. \& COLWELL, R.K. 2001. Quantifying biodiversity: procedures and pitfalls in the measurement and comparison of species richness. Ecol. Lett. 4:379-391

KOSTE, W. 1978. Rotatoria. Die Rädertiere Mitteleuropas. Ein Bestimmungswerk berg. Von Max Voigt. Überordnung Monogononta. Volume I-II. Gebruder Borntrager, Berlim

KOSTE, W. \& ROBERTSON, B. 1983. Taxonomic studies of the Rotifera (Phylum Aschelminthes) from a Central Amazonian varzea lake, Lago Camaleão (Ilha de Marchantaria, Rio Solimões, Amazonas, Brazil). Amazoniana. 8(2):225-254.
LAMPARELLI, M.C. 2004. Graus de trofia em corpos d'água do Estado de São Paulo: avaliação dos métodos de monitoramento. Tese de Doutorado, Universidade de São Paulo, São Paulo.

LANSAC-TÔHA, F.A., BONECKER, C.C., VELHO, L.F.M. \& LIMA, A.F. 1997. Comunidade zooplanctônica; In A planície de inundação do alto rio Paraná: aspectos físicos, químicos, biológicos e socioeconômicos (A.E.A.M. Vazzoler, A.A.Agostinho \& N.S. Hahn, ed.). Editora da Universidade Estadual de Maringá, Maringá, p.117-155.

LANSAC-TÔHA, F.A, BONECKER, C.C, VELHO, L.F.M., SIMÕES, N.R., DIAS, J.D., ALVES, G.M. \& TAKAHASHI, E.M. 2009. Biodiversity of zooplankton communities in the Upper Paraná River floodplain: interannual variation from long-term studies. Braz. J. Biol. $=$ Rev. Bras. Biol. 69(Suppl 2):539-49. http://www. ncbi.nlm.nih.gov/pubmed/19738961.

LATINI, A.O. \& PETRERE Jr, M. 2004. Reduction of native fish fauna by alien species: an example from Brazilian freshwater tropical lakes. Fisheries. Manag. Ecol. 11(2): 71-79.

MACKERETH, F.J.H., HERON, J. \& TALLING, J.F. 1978. Water analysis. Freshwater Biological Association, Scientific Publication $\mathrm{N}^{\circ}$ 36,.Titus Wilson and Son, Kendal.

MAIA-BARBOSA, P.M., PEIXOTO, R.S. \& GUIMARÃES, A.S. 2008. Zooplankton in littoral waters of a tropical lake: a revisited biodiversity. Braz. J. Biol. 68(Suppl 4):1069-1078.

MAIA-BARBOSA, P.M., BARBOSA, L.G., BRITO, S.L., GARCIA, F., BARROS, C.F.A., SOUZA, M.B.G., MELLO, N., GUIMARÃES, A.S. \& BARBOSA, F.A.R. 2010. Limnological changes in Dom Helvécio Lake (South-East Brazil): natural and anthropogenic causes. Braz. J. Biol. = Rev. Bras. Biol. 70(3):795802.http://www.scielo.br/scielo.php?pid=S151969842010000400010\&script=sci_arttext.

MATSUMURA-TUNDISI, T. 1986. Latitudinal distribution of Calanoida Copepods in freshwater aquatic systems of Brazil. Braz. J. Biol. = Rev. Bras. Biol. 46(3):527-553.

MATSUMURA-TUNDISI, T. \& TUNDISI, J.G. 2011. Checklist dos Copepoda Calanoida de água doce do Estado de São Paulo. Biota Neotrop. 11(1a): http://www.biotaneotropica.org.br/v11n $1 \mathrm{a} / \mathrm{pt} /$ fullpaper?bn0251101a2011+pt

MELLO, C.L., METELO, C.M.S., SUGUIO, K. \& KOHLER,H.C.

1999. Quaternary sedimentation, neotectonics, and evolution of the Doce river middle valley lake system (southeastern Brazil). Revista do Instituto Geológico. 20:29-36.

MITTERMEIER, R.A., MYERS, N., THOMSEN, J.B.,FONSECA,G.A.B. da \& OLIVIERI, S. 1998. Biodiversity hotspots and major tropical wilderness areas: approaches to setting conservation priorities. Conserv. Biol. 12:516-520.

MORETTO, E.M., 2001. Diversidade zooplanctônica e variáveis limnológicas das regiões limnética e litorânea de cinco lagoas do vale do Rio Doce-MG, e suas relações com o entorno. Dissertação de Mestrado.Universidade de São Paulo, São Carlos

MYERS, N., MITTERMEIER, R.A., MITTERMEIER, C.G., FONSECA, G.A.B da \& KENT, J. 2000. Biodiversity hotspots for conservation priorities. Nature 403:853-858. 
PAGGI, J.C., \& JOSÉ DE PAGGI, S. 1990. Zooplâncton de ambientes lóticos e lênticos do rio Paraná médio. Acta Limnol.Brasil. 3:685-719.

PINTO-COELHO, R.M., BEZERRA-NETO, J.F., MIRANDA, F., MOTA, T.G., RESCK, R., SANTOS, A.M., MAIA-BARBOSA, P.M., MELLO, N.A.S.T., MARQUES, M.M., CAMPOS, M.O. \& BARBOSA, F.A.R. 2008. The inverted trophic cascade in tropical plankton communities: impacts of exotic fish in the Middle Rio Doce lake district, Minas Gerais, Brazil. Braz. J. Biol. = Rev. Bras. Biol. 68:1025-37. http://www.ncbi.nlm.nih.gov/pubmed/19197473.

RAMSAR. 2010. The RAMSAR List of Wetlands of International Importance. Electronic Database accessible at http://www.ramsar.org/pdf/sitelist_order.pdf.

REID, J.W. 1985. Chave de identificação e lista de referências bibliográficas para as espécies continentais sulamericanas de vida livre da ordem Cyclopoida (Crustacea, Copepoda). Boletim Zoológico da Universidade de São Paulo. 9:17-143.

ROCHA C.E.F. 1998. New morphological characters useful for the taxonomy of the genus Microcyclops (Copepoda, Cyclopoida). J. Mar. Syst. 15:425-431.

ROCHA, O., SANTOS-WISNIEWSKI, M.J. \& MATSUMURA-TUNDISI, T. Checklist dos Cladocera de água doce do Estado de São Paulo, Brasil. Biota Neotrop.11(1a):http://www.biotaneotropica.org.br/v11n1a/ pt/abstract?inventory+bn0271101a2011.SANTOSWISNIEWSKI,M.J.,MATSUMURA-TUNDISI, T., NEGREIROS, N.F., SILVA, L.C., SANTOS, R.M. and ROCHA, O. 2011. O estado atual do conhecimento da diversidade dos Cladocera (Crustacea, Branchiopoda) nas águas doces do estado de Minas Gerais. Biota Neotrop. 11(3): http://www.scielo.br/pdf/bn/v11n3/a24v11n3.pdf.

SEGERS,H.1995.Rotifera. The lecanidae (Monogononta). In Guides to the identification of the Microinvertebrates of the Continental Waters of the World (H.J. Dumont \& T. Nogrady, ed.). SPB Academic Publishing, Amsterdam, The Netherlands.
SEGERS, H. 2008. Global diversity of rotifers (Rotifera) in freshwater. Hydrobiologia 595:49-59.

SEGERS, H. \& DUMONT, H.J. 1995. 102+ rotifer species (Rotifera: Monogononta) in Broa reservoir (SP., Brazil) on 26 August 1994, with the description of three new species. Hydrobiologia 316(3):183 - 197.

SEGERS, H and SMET, W.H. 2008. Diversity and endemism in Rotifera: a review, and Keratella Bory de St Vincent. Biodivers. Conserv. 17:303-316.

SENDACZ, S. 1993. Distribuição geográfica de alguns organismos zooplanctônicos na América do Sul. Acta Limnol.Brasil. 6:31-41.

SILVA, W.M. 2008. Diversity and distribution of the freeliving freshwater Cyclopoida (Copepoda: Crustacea) in the Neotropics. Brazil. Braz. J. Biol. = Rev. Bras. Biol. 68:1099-1106.

SILVA, W.M. \& MATSUMURA-TUNDISI, T. 2011. Checklist dos Copepoda Cyclopoida de vida livre de água doce do Estado de São Paulo, Brasil. Biota Neotrop. 11(1a):http://www.biotaneotropica.org.br/v11n1a/en/abst ract?inventory+bn0261101a2011

SMIRNOV, N.N. 1996. Cladocera: the Chydorinae and Sayciinae (Chydoridae) of the world. In Guides to the identification of the Microinvertebrates of the Continental Waters of the World (H. J. Dumont, ed.). SPB Academic Publishing, Amsterdam, The Netherlands.

SOARES,F.S.,TUNDISI,J.G.\&MATSUMURA-TUNDISI, T. 2011. Checklist de Rotifera de água doce do Estado de São Paulo, Brasil. Biota Neotrop. 11(1a):http://www. biotaneotropica.org.br/v11n1a/en/abstract?inventory+bn $0231101 \mathrm{a} 2011$

TUNDISI, J.G. 1997. Climate. In Limnological Studies on the Rio Doce Valley Lakes, Brazil (J.G. Tundisi \& Y. Saijo, ed.). Brazilian Academy of Sciences, São Carlos. p. 7-11.

TUNDISI, J. G. \& SAIJO, Y. 1997. Limnological Studies on the Rio Doce Valley Lakes, Brazil. Brazilian Academy of Sciences. University of São Paulo. São Carlos. 
Table 3: List of zooplankton species from 18 lakes of the middle Rio Doce basin, Minas Gerais, Brazil. * Data from Maia-Barbosa et al. (2008)

\begin{tabular}{|c|c|c|c|c|c|c|c|c|c|c|c|c|c|c|c|c|c|c|c|c|}
\hline & \multicolumn{10}{|c|}{ Lakes Inside PERD } & \multicolumn{10}{|c|}{ Lakes OutsidePERD } \\
\hline & \multirow{2}{*}{$\begin{array}{l}\text { AN } \\
\text { Lim }\end{array}$} & \multirow{2}{*}{\begin{tabular}{|l} 
CA \\
Lim
\end{tabular}} & \multirow{2}{*}{$\frac{\mathrm{CE}}{\mathrm{Lim}}$} & \multicolumn{2}{|c|}{$\mathrm{DH}$} & \multirow{2}{*}{\begin{tabular}{|l|} 
GA \\
Lim \\
\end{tabular}} & \multirow{2}{*}{\begin{tabular}{|l} 
GN \\
Lim
\end{tabular}} & \multicolumn{2}{|c|}{ PT } & \multirow{2}{*}{$\frac{\mathrm{SH}}{\mathrm{Lim}}$} & \multirow{2}{*}{$\begin{array}{l}A C \\
\operatorname{Lim}\end{array}$} & \multirow{2}{*}{$\begin{array}{l}\mathrm{AL} \\
\mathrm{Lim}\end{array}$} & \multirow{2}{*}{\begin{tabular}{|l|} 
AM \\
Lim
\end{tabular}} & \multirow{2}{*}{$\frac{B A}{\operatorname{Lim}}$} & \multirow{2}{*}{$\begin{array}{c}\mathrm{FE} \\
\mathrm{Lim}\end{array}$} & \multirow{2}{*}{\begin{tabular}{|l|} 
FN \\
Lim \\
\end{tabular}} & \multirow{2}{*}{\begin{tabular}{|c|}
$\mathrm{JA}$ \\
$\mathrm{Lim}$
\end{tabular}} & \multirow{2}{*}{$\begin{array}{c}\mathrm{PA} \\
\operatorname{Lim}\end{array}$} & & VE \\
\hline & & & & Lim & Lit* & & & Lim & Lit & & & & & & & & & & & Lim \\
\hline COPEPODA & & & & & & & & & & & & & & & & & & & & \\
\hline Harpacticoida & & & & & & & & & & & & & & & & & & & & \\
\hline Harpacticoida NI & & & & & & & & & & & & 1 & 1 & & & & 1 & & & 1 \\
\hline Família Canthocamptidae & & & & & & & & & & & & & & & & & & & & \\
\hline Attheyella fuhrmani Thieband, 1914 & & & & & 1 & & & & & & & & & & & & & & & \\
\hline Elaphoidella sp & & & & & 1 & & & & & & & & & & & & & & & \\
\hline Família Parastenocarididae & & & & & & & & & & & & & & & & & & & & \\
\hline Potamocaris sp. & & & & 1 & & & & & & & & & 1 & & & & & & & \\
\hline Cyclopoida & & & & & & & & & & & & & & & & & & & & \\
\hline Família Cyclopidae & & & & & & & & & & & & & & & & & & & & \\
\hline Ectocyclops herbsti Dussart, 1984 & & & & & 1 & & & & 1 & & & & & & & & & & & \\
\hline Ectocyclops rubescens Brady, 1904 & & & & & 1 & & & & 1 & & & & 1 & & & & & & & \\
\hline Haplocyclops sp & & & & & & & & & & & & & 1 & & & & & & & \\
\hline Homocyclops ater (Herrick, 1882) & & & & & 1 & & & & & & & & & & & & & & & \\
\hline Macrocyclops albidus (Jurine, 1820) & & & & & 1 & & & & & & & & & & & & & & & \\
\hline Mesocyclops longisetus (Thiébaud, 1914) & & & & & 1 & & & & & & & & 1 & & & & & & & \\
\hline Mesocyclops meridianus (Kiefer, 1926) & & 1 & & & 1 & & & & 1 & & 1 & & 1 & & & & & & & \\
\hline Mesocyclops ogunnus Onabamiro, 1957 & & & & 1 & 1 & & & & 1 & & & & & & & & & & & \\
\hline Mesocyclops sp. & 1 & & 1 & 1 & & & 1 & 1 & & 1 & & 1 & & & 1 & 1 & & 1 & 1 & 1 \\
\hline Metacyclops sp. & & & & 1 & & & & & & & & & & & 1 & & & & & \\
\hline Microcyclops alius Kiefer, 1935 & & & & & 1 & & & & 1 & & & & & & & & & & & \\
\hline Microcyclops anceps (Richard, 1897) & & 1 & & & 1 & & 1 & 1 & 1 & & 1 & & 1 & & & & 1 & 1 & & \\
\hline Microcyclops ceibaensis (Marsh, 1919) & & & & 1 & & & & & 1 & & & & 1 & & & & & & & \\
\hline Microcyclops finitimus Dussart, 1984 & & & & & & & & & 1 & & & & & & & & & & & \\
\hline Neutrocyclops brevifurca (Lowndes, 1934) & & & & & 1 & & & & & & & & 1 & & & & & & & \\
\hline Paracyclops chiltoni (Thomson G.M., 1883) & & & & 1 & 1 & & & & & & & & 1 & & & & & & & \\
\hline Thermocyclops minutus (Lowndes, 1934) & 1 & 1 & 1 & 1 & 1 & 1 & 1 & 1 & & 1 & 1 & 1 & 1 & 1 & 1 & 1 & 1 & 1 & 1 & 1 \\
\hline $\begin{array}{l}\begin{array}{l}\text { Tropocyclops prasinus meridionalis (Kiefer, } \\
\text { 1931) }\end{array} \\
\end{array}$ & & 1 & & 1 & 1 & & 1 & & 1 & & 1 & 1 & 1 & & & & 1 & 1 & & 1 \\
\hline Calanoida & & & & & & & & & & & & & & & & & & & & \\
\hline Família Diaptomidae & & & & & & & & & & & & & & & & & & & & \\
\hline Notodiaptomus cearensis (Wright S., 1936) & & & & & & & & 1 & 1 & & & & & & & & & & & \\
\hline $\begin{array}{l}\text { Notodiaptomus dubius Dussart \& Matsumura- } \\
\text { Tundisi.1985 }\end{array}$ & & & & & & & & & & & & & 1 & & & & & & & \\
\hline Notodiaptomus isabelae (Wright S., 1936) & 1 & 1 & 1 & 1 & 1 & 1 & 1 & 1 & & & 1 & 1 & & 1 & 1 & 1 & 1 & 1 & & 1 \\
\hline subtotal & 3 & 5 & 3 & 9 & 16 & 2 & 5 & 5 & 10 & 2 & 5 & 5 & 13 & 2 & 4 & 3 & 5 & 5 & 2 & 5 \\
\hline CLADOCERA & & & & & & & & & & & & & & & & & & & & \\
\hline Família Bosminidae & & & & & & & & & & & & & & & & & & & & \\
\hline Bosmina hagmanni Stingelin, 1904 & 1 & 1 & & 1 & 1 & & 1 & 1 & 1 & & 1 & 1 & 1 & 1 & & & 1 & 1 & & 1 \\
\hline Bosmina freyi De Melo \& Hebert, 1994 & & 1 & & 1 & & & 1 & & & & & & & & & & & & & \\
\hline
\end{tabular}




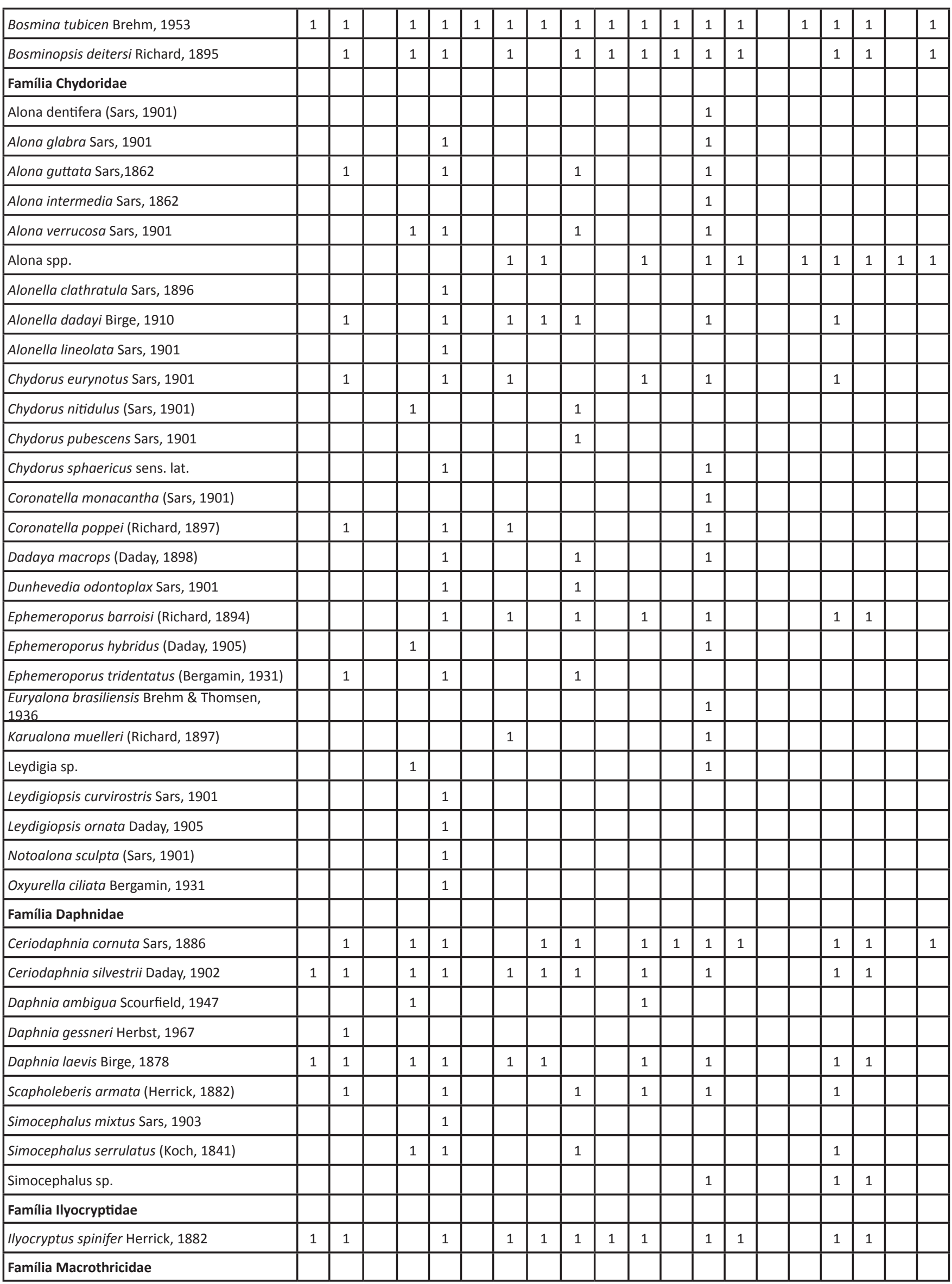




\begin{tabular}{|c|c|c|c|c|c|c|c|c|c|c|c|c|c|c|c|c|c|c|c|c|}
\hline Grimaldina brazzai Richard, 1892 & & & & & & & & & & & & & 1 & & & & & & & \\
\hline Macrothrix elegans Sars, 1901 & & & & & 1 & & 1 & & 1 & & & & 1 & & & & & & & \\
\hline Macrothrix paulensis (Sars, 1900) & & & & & 1 & & & 1 & 1 & & & & & & & & & & & \\
\hline Macrothrix squamosa Sars, 1901 & & 1 & & & 1 & & & & 1 & & & & 1 & & & & & & & \\
\hline Macrothrix sp. & & & & & & & 1 & & & & & & 1 & & & & 1 & 1 & & \\
\hline Streblocerus pygmaeus Sars, 1901 & & & & 1 & & & & & 1 & & & & & & & & & & & \\
\hline \multicolumn{21}{|l|}{ Família Moinidae } \\
\hline Moina minuta Hansen, 1899 & & 1 & & 1 & & & 1 & & & & 1 & & 1 & & & & & & & \\
\hline Moina reticulata (Daday, 1905) & & & & 1 & & & & & 1 & & & & 1 & & & & & & & \\
\hline \multicolumn{21}{|l|}{ Família Sididae } \\
\hline Diaphanosoma birgei Korineck, 1981 & & 1 & & 1 & 1 & & 1 & 1 & 1 & 1 & 1 & 1 & 1 & 1 & 1 & 1 & 1 & 1 & & 1 \\
\hline Diaphanosoma brevireme Sars, 1901 & 1 & & & 1 & & & & 1 & 1 & & & & 1 & 1 & & & & & & \\
\hline Diaphanosoma fluviatile Hansen, 1899 & & & & & & & & & 1 & & & & & & & & & & & \\
\hline Diaphanosoma spinulosum Herbst, 1967 & & & & & & & 1 & & & & & & 1 & & & & & & & \\
\hline Pseudosida bidentada Herrick, 1884 & & & & & 1 & & & & 1 & & & & 1 & & & & & & & \\
\hline Pseudosida ramosa (Daday, 1904) & & & & & & & & & 1 & & & & 1 & & & & & & & \\
\hline subtotal & 6 & 18 & 0 & 18 & 32 & 1 & 18 & 11 & 27 & 4 & 14 & 5 & 37 & 8 & 1 & 3 & 16 & 12 & 1 & 6 \\
\hline \multicolumn{21}{|l|}{ ROTIFERA } \\
\hline \multicolumn{21}{|l|}{ Ordem Ploima } \\
\hline \multicolumn{21}{|l|}{ Família Asplanchnidae } \\
\hline Asplanchna sp. & & & & & & & 1 & & 1 & & 1 & & & & & & 1 & 1 & & \\
\hline \multicolumn{21}{|l|}{ Família Brachionidae } \\
\hline Anuraeopsis fissa Gosse, 1851 & & 1 & & & 1 & & 1 & 1 & 1 & & & & 1 & & & & 1 & & & \\
\hline Anuraeopsis navicula Rousselet, 1911 & & & & 1 & 1 & & & 1 & 1 & & 1 & & 1 & & & & 1 & & & \\
\hline Anuraeopsis sp. & 1 & 1 & 1 & 1 & & 1 & & 1 & & 1 & 1 & 1 & 1 & 1 & 1 & 1 & 1 & 1 & 1 & 1 \\
\hline Brachionus angularis Gosse, 1851 & 1 & 1 & 1 & 1 & 1 & & 1 & & 1 & 1 & 1 & 1 & 1 & 1 & & & 1 & 1 & 1 & 1 \\
\hline Brachionus bidentatus Anderson, 1889 & & 1 & & 1 & & & & & & & & & & & & & & & & \\
\hline Brachionus calyciflorus Pallas, 1766 & & 1 & & & & & & & & & & & 1 & & & & & 1 & & \\
\hline Brachionus dolabratus Harring, 1914 & 1 & 1 & 1 & 1 & & & & 1 & & & 1 & 1 & & 1 & 1 & & 1 & 1 & 1 & 1 \\
\hline Brachionus falcatus Zacharias, 1898 & 1 & 1 & 1 & 1 & 1 & & 1 & 1 & 1 & 1 & 1 & 1 & 1 & 1 & 1 & & 1 & 1 & 1 & 1 \\
\hline Brachionus forficula Wierzejski, 1891 & & & & 1 & & & & & & & & & & & & & & & & \\
\hline Brachionus mirus Daday, 1905 & 1 & 1 & 1 & 1 & 1 & 1 & 1 & 1 & 1 & 1 & 1 & 1 & 1 & 1 & 1 & 1 & 1 & 1 & 1 & 1 \\
\hline Brachionus quadridentatus Hermann, 1783 & & & & 1 & 1 & & & 1 & 1 & & 1 & & 1 & & & & 1 & 1 & & \\
\hline Kellicottia bostoniensis (Rousselet, 1908) & & 1 & & & 1 & & & & & & 1 & & & & & & 1 & & & \\
\hline Keratella americana Carlin, 1943 & 1 & 1 & 1 & 1 & 1 & 1 & 1 & 1 & 1 & 1 & 1 & 1 & 1 & 1 & 1 & 1 & 1 & 1 & 1 & 1 \\
\hline Keratella cochlearis (Gosse, 1851) & 1 & 1 & & 1 & 1 & & & & & & 1 & & 1 & & & 1 & 1 & 1 & & \\
\hline Keratella lenzi Hauer, 1953 & & 1 & & 1 & 1 & & & 1 & 1 & & 1 & & 1 & 1 & & & 1 & 1 & & \\
\hline Keratella tropica (Apstein, 1907) & & 1 & & 1 & 1 & & 1 & 1 & 1 & 1 & & & 1 & & & & 1 & 1 & & \\
\hline Plationus patulus macracanthus (Daday, 1905) & & 1 & & & & & & & & & & & 1 & & & & & & & \\
\hline Plationus patulus (Müller, 1786) & 1 & 1 & & 1 & 1 & & 1 & 1 & 1 & & 1 & & 1 & 1 & & & 1 & 1 & & 1 \\
\hline Platyias leloupi Gillard, 1967 & & & & & & & & & 1 & & & & 1 & & & & & & & \\
\hline Platyias quadricornis (Ehrenberg, 1832) & 1 & 1 & & & 1 & & 1 & 1 & 1 & & 1 & & 1 & & & & 1 & 1 & & \\
\hline $\begin{array}{l}\text { Platyias quadricornis quadricornis (Ehrenberg, } \\
\text { 1832) }\end{array}$ & & & & & & & & & & & & & 1 & & & & & & & \\
\hline
\end{tabular}




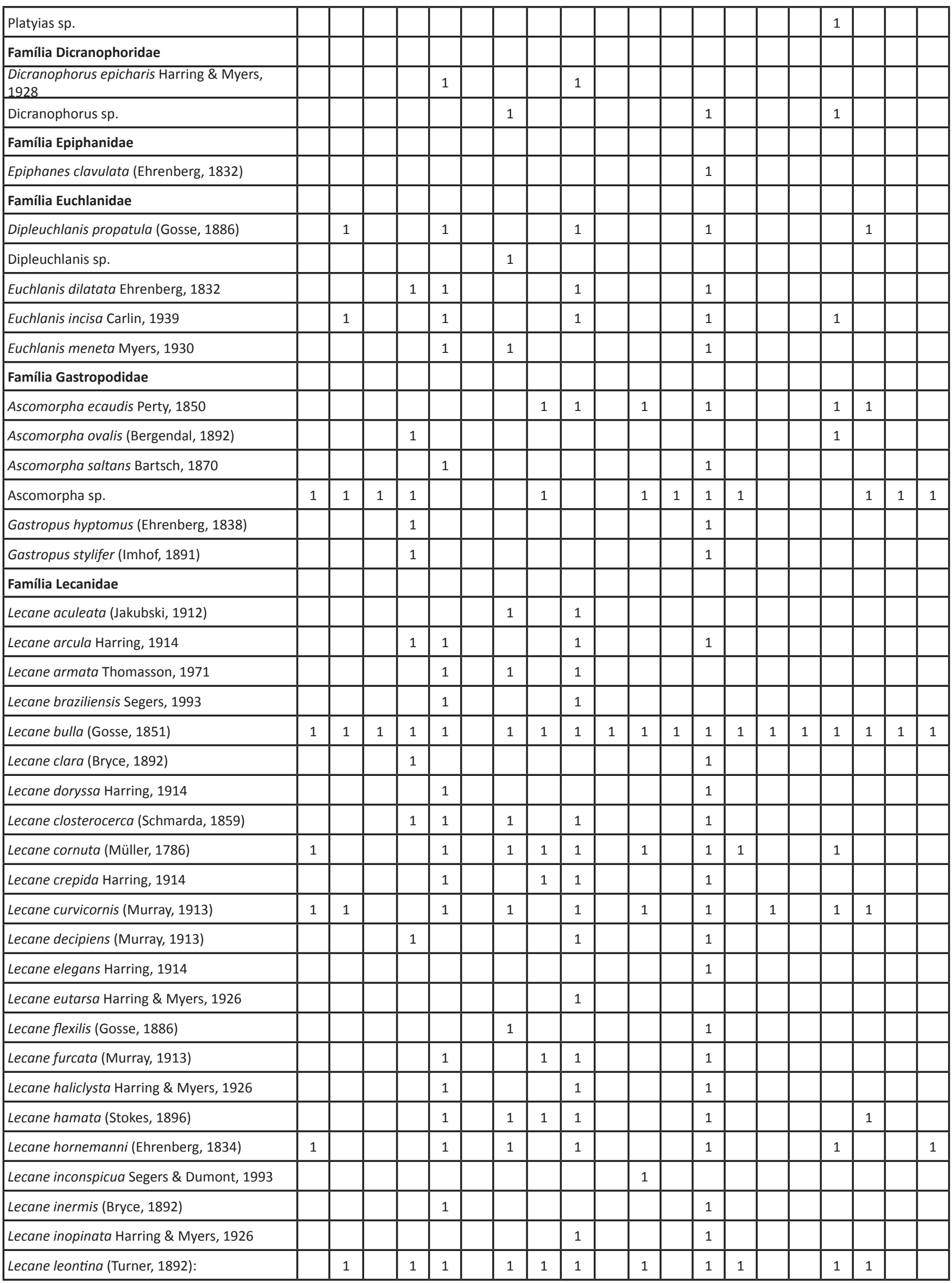




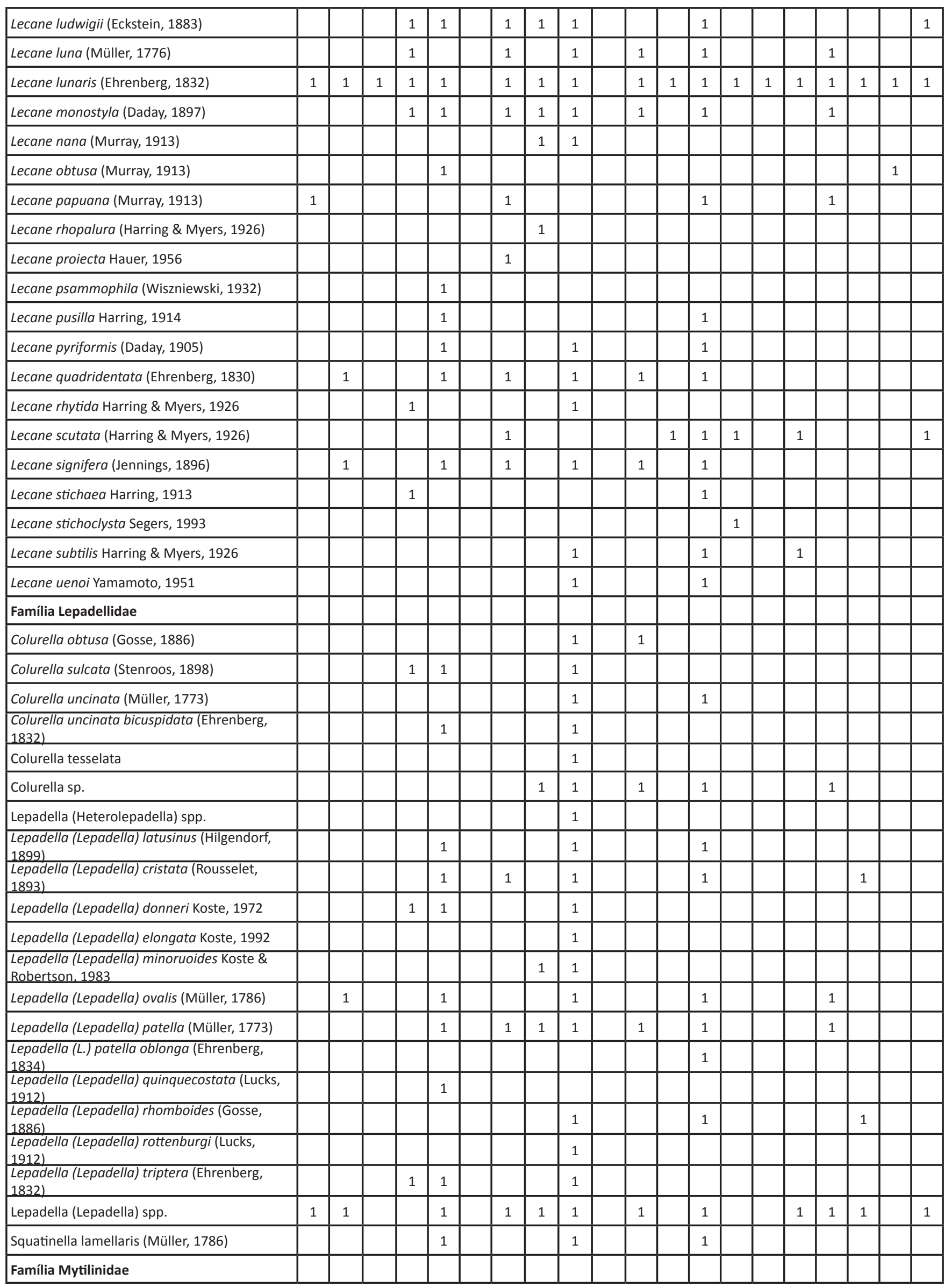




\begin{tabular}{|c|c|c|c|c|c|c|c|c|c|c|c|c|c|c|c|c|c|c|c|c|}
\hline Lophocharis salpina (Ehrenberg, 1834) & & & & & 1 & & & & 1 & & & & & & & & & & & \\
\hline Mytilina acanthophora Hauer, 1938 & & & & & & & & & & & 1 & & 1 & & & & 1 & 1 & & \\
\hline Mytilina bisulcata (Lucks, 1912) & & & & 1 & & & 1 & 1 & 1 & & 1 & & 1 & & & & 1 & 1 & & \\
\hline Mytilina mucronata (Müller, 1773) & & & & & & & 1 & & & & & & & & & & & & & \\
\hline Mytilina ventralis (Ehrenberg, 1830) & & & & 1 & & & 1 & 1 & 1 & & & & 1 & & & & & 1 & 1 & \\
\hline Mytilina ventralis ventralis (Ehrenberg, 1830) & & & & & 1 & & & & & & & & 1 & & & & & & & \\
\hline Mytilina sp. & & 1 & & & & & & & & & & & 1 & & & & & & & \\
\hline Família Notommatidae & & & & & & & & & & & & & & & & & & & & \\
\hline Cephalodella rotunda Wulfert, 1937 & & & & & & & & & & & & & 1 & & & & & & & \\
\hline Cephalodella forficula (Ehrenberg, 1830) & & & & & 1 & & & & 1 & & & & 1 & & & & & & & \\
\hline Cephalodella gibba (Ehrenberg, 1830) & & & & & & & & & 1 & & & & 1 & & & & & & & \\
\hline Cephalodella spp. & & 1 & & & 1 & & 1 & 1 & 1 & & 1 & & 1 & & & & 1 & & & \\
\hline Monommata aequalis (Ehrenberg, 1830) & & 1 & & 1 & & & & & & & & & & & & & & & & \\
\hline Monommata sp. & & & & & 1 & & 1 & & 1 & & & & 1 & & & & & 1 & & \\
\hline Notommata copeus Ehrenberg, 1834 & & & & & & & & & 1 & & & & & & & & & & & \\
\hline Notommata spp. & & & & & & & & & 1 & & & & 1 & & & & & & & \\
\hline Resticula sp. & & & & & & & & & 1 & & & & & & & & & & & \\
\hline Notommatidae NI & & 1 & & & & & & & & & 1 & & 1 & & & & & 1 & & \\
\hline Família Scaridiidae & & & & & & & & & & & & & & & & & & & & \\
\hline Scaridium longicaudum (Müller, 1786) & & & & & & & & & 1 & & & & & & & & & & & \\
\hline Família Synchaetidae & & & & & & & & & & & & & & & & & & & & \\
\hline Polyarthra dolichoptera Idelson, 1925 & & & & & & & & & & & & & 1 & & & & & & & \\
\hline Polyarthra sp. & 1 & 1 & & 1 & 1 & & 1 & 1 & 1 & 1 & 1 & & 1 & 1 & & & 1 & 1 & 1 & \\
\hline Synchaeta sp. & & & & & & & & & & & & & 1 & & & & & & & \\
\hline Família Trichocercidae & & & & & & & & & & & & & & & & & & & & \\
\hline Trichocerca bicristata (Gosse, 1887) & & & & & & & 1 & & 1 & & & & 1 & & & & & & & \\
\hline Trichocerca bidens (Lucks, 1912) & & & & & & & & & 1 & & & & & & & & & & & \\
\hline Trichocerca iernis (Gosse, 1887) & & & & & 1 & & & & 1 & & & & 1 & & & & & & & \\
\hline Trichocerca scipio (Gosse, 1886) & & & & & & & 1 & & & & & & 1 & & & & & & & \\
\hline $\begin{array}{l}\text { Trichocerca elongata braziliensis (Murray, } \\
1913 \text { ) }\end{array}$ & & & & & 1 & & & & 1 & & & & 1 & & & & & & & \\
\hline Trichocerca cavia (Gosse, 1886) & & & & & & & & & 1 & & & & & & & & & & & \\
\hline Trichocerca cylindrica (Imhof, 1891) & & & & & & & & 1 & 1 & & & & & & & & & & & \\
\hline Trichocerca chattoni (de Beauchamp, 1907) & & & & & 1 & & & 1 & & 1 & 1 & & & & & & & & & \\
\hline Trichocerca flagellata Hauer, 1937 & & & & & & & & & & & & & 1 & & & & & & & \\
\hline Trichocerca macera (Gosse, 1886) & & & & & & & & & & & & & 1 & & & & & & & \\
\hline Trichocerca insignis (Herrick, 1885) & & & & & & & & & 1 & & & & 1 & & & & & & & \\
\hline Trichocerca pusilla (Jennings, 1903) & 1 & 1 & 1 & 1 & 1 & 1 & 1 & 1 & 1 & 1 & 1 & 1 & 1 & 1 & 1 & 1 & 1 & 1 & 1 & 1 \\
\hline Trichocerca rattus (Müller, 1776) & & & & 1 & 1 & & 1 & & & & & 1 & 1 & & & & & 1 & & \\
\hline Trichocerca similis (Wierzejski, 1893) & & & & & 1 & & 1 & 1 & 1 & & 1 & & 1 & 1 & & & 1 & 1 & & 1 \\
\hline Trichocerca stylata (Gosse, 1851) & 1 & 1 & & 1 & 1 & & & & & 1 & 1 & & 1 & 1 & 1 & & 1 & & 1 & 1 \\
\hline Trichocerca tenuior (Gosse, 1886) & & & & & & & & & & & & & 1 & & & & & & & \\
\hline Trichocerca tigris (Müller, 1786) & & & & & & & & & 1 & & & & & & & & & & & \\
\hline Família Trichotriidae & & & & & & & & & & & & & & & & & & & & \\
\hline
\end{tabular}




\begin{tabular}{|c|c|c|c|c|c|c|c|c|c|c|c|c|c|c|c|c|c|c|c|c|}
\hline Trichotria tetractis (Ehrenberg, 1830) & & & & & 1 & & 1 & & 1 & & & & 1 & & & & 1 & & 1 & \\
\hline Macrochaetus collinsii (Gosse, 1867) & & & & & 1 & & 1 & & 1 & & & & 1 & & & & 1 & & & \\
\hline Macrochaetus longipes Myers, 1934 & & 1 & & & 1 & & & & 1 & & & & 1 & & & & & & & \\
\hline Macrochaetus sericus (Thorpe, 1893) & & & & 1 & 1 & & 1 & & 1 & & & & 1 & & & & 1 & 1 & & \\
\hline Macrochaetus sp. & & & & & & & & 1 & & & 1 & 1 & & & 1 & 1 & 1 & 1 & & \\
\hline \multicolumn{21}{|l|}{ Ordem Flosculariaceae } \\
\hline \multicolumn{21}{|l|}{ Família Conochilidae } \\
\hline $\begin{array}{l}\text { Conochilus (Conochiloides) coenobasis } \\
\text { (Skorikov. 1914) }\end{array}$ & & & & & 1 & & & & 1 & & 1 & & 1 & & & & 1 & 1 & & \\
\hline $\begin{array}{l}\text { Conochilus (Conochiloides) dossuarius Hudson, } \\
1885\end{array}$ & & & & 1 & & & & 1 & 1 & & & & 1 & & & & & & & \\
\hline $\begin{array}{l}\begin{array}{l}\text { Conochilus (Conochiloides) natans (Seligo, } \\
1900)\end{array} \\
\end{array}$ & & & & & & & & & & & & & 1 & & & & & & & \\
\hline $\begin{array}{l}\text { Conochilus (Conochilus) unicornis Rousselet, } \\
1892\end{array}$ & & & & 1 & & & & & & & 1 & & 1 & & & & 1 & & & \\
\hline Conochilus sp. & 1 & 1 & & 1 & & & 1 & 1 & 1 & 1 & 1 & 1 & 1 & 1 & 1 & 1 & 1 & 1 & & 1 \\
\hline \multicolumn{21}{|l|}{ Família Filiniidae } \\
\hline Filinia longiseta (Ehrenberg, 1834) & 1 & 1 & & 1 & 1 & & 1 & & & 1 & 1 & 1 & 1 & 1 & 1 & & 1 & 1 & & 1 \\
\hline Filinia opoliensis (Zacharias, 1898) & & & & 1 & & & 1 & & 1 & & & & & & & & & 1 & & \\
\hline Filinia pejleri Hutchinson, 1964 & & & & & & & & & & & & & 1 & & & & & & & \\
\hline Filinia terminalis (Plate, 1886) & & & & & & & & 1 & 1 & & & & & & & & & & & \\
\hline \multicolumn{21}{|l|}{ Família Flosculariidae } \\
\hline Beauchampiella eudactylota (Gosse, 1886) & & & & & & & & & & & & & 1 & & & & & & & \\
\hline Ptygura elsteri Koste, 1972 & & & & & & & & & 1 & & & & & & & & & & & \\
\hline Ptygura furcillata (Kellicott, 1889) & & & & & & & & & 1 & & & & & & & & & & & \\
\hline Ptygura libera Myers, 1934 & 1 & 1 & 1 & 1 & & 1 & 1 & 1 & & 1 & 1 & 1 & 1 & 1 & 1 & 1 & 1 & 1 & 1 & 1 \\
\hline Ptygura spp. & & & & 1 & & & & 1 & 1 & & & & & & & & & & & \\
\hline Sinantherina sp. & & & & & 1 & & & 1 & 1 & & & & 1 & 1 & & & 1 & & & \\
\hline \multicolumn{21}{|l|}{ Família Hexarthridae } \\
\hline Hexarthra intermedia (Wiszniewski, 1929) & 1 & 1 & 1 & 1 & 1 & 1 & 1 & 1 & 1 & 1 & 1 & 1 & 1 & 1 & 1 & 1 & 1 & 1 & 1 & 1 \\
\hline \multicolumn{21}{|l|}{ Família Testudinellidae } \\
\hline Testudinella amphora Hauer, 1938 & & & & & 1 & & & & 1 & & & & & & & & & & & \\
\hline Testudinella parva (Ternetz, 1892) & & & & & & & 1 & & 1 & & & & & & & & & & & \\
\hline Testudinella emarginula (Stenroos, 1898) & & & & & & & & & 1 & & & & & & & & & & & \\
\hline Testudinella mucronata (Gosse, 1886) & & & & & & & & & & & & & 1 & & & & & & & \\
\hline Testudinella ohlei Koste, 1972 & & & & & 1 & & 1 & & 1 & & & & & & & & & & & \\
\hline Testudinella patina (Hermann, 1783) & & & & 1 & 1 & & 1 & & 1 & & & & 1 & & & & & & & \\
\hline \multicolumn{21}{|l|}{ Ordem Collothecaceae } \\
\hline \multicolumn{21}{|l|}{ Família Collothecidae } \\
\hline Collotheca tenuilobata (Anderson, 1889) & & & & & & & & & & & & & 1 & & & & & & & \\
\hline Collotheca sp. & 1 & 1 & 1 & 1 & 1 & 1 & 1 & 1 & 1 & 1 & 1 & 1 & 1 & 1 & 1 & 1 & 1 & 1 & 1 & 1 \\
\hline \multicolumn{21}{|l|}{ Subclasse Bdelloidea } \\
\hline Bdeloidea & 1 & 1 & 1 & 1 & 1 & & 1 & 1 & 1 & 1 & 1 & 1 & 1 & 1 & 1 & 1 & 1 & 1 & 1 & 1 \\
\hline \multicolumn{21}{|l|}{ Família Philodinidae } \\
\hline Dissotrocha aculeata (Ehrenberg, 1832) & 1 & & & 1 & 1 & & & & 1 & & 1 & & 1 & & & 1 & & 1 & 1 & \\
\hline Dissotrocha macrostyla (Ehrenberg, 1838) & & & & & & & & & & & & & 1 & & & & & & & \\
\hline Dissotrocha sp. & & & & & & & 1 & & & & 1 & & & & & & & & & \\
\hline
\end{tabular}




\begin{tabular}{|c|c|c|c|c|c|c|c|c|c|c|c|c|c|c|c|c|c|c|c|c|}
\hline Macrotrachela sp. & & & & & & & 1 & & & & 1 & & & & & & & & & \\
\hline Rotaria neptunia (Ehrenberg, 1830) & & & & & & & & & & & & & 1 & & & & & & & \\
\hline Rotaria sp. & & & & & & & 1 & & & & & & & & & & & & & \\
\hline subtotal & 27 & 41 & 14 & 54 & 81 & 7 & 61 & 47 & 109 & 17 & 51 & 19 & 119 & 26 & 17 & 17 & 54 & 45 & 20 & 23 \\
\hline PROTOZOA & & & & & & & & & & & & & & & & & & & & \\
\hline Rhizopoda & & & & & & & & & & & & & & & & & & & & \\
\hline Família Arcellidae & & & & & & & & & & & & & & & & & & & & \\
\hline Arcella brasiliensis Cunha, 1913 & & & & & & & & & & & & & 1 & & & & & & & \\
\hline Arcella arenaria Greeff, 1866 & & & & & & & & & & & & & 1 & & & & & & & \\
\hline Arcella irregularis Motti, 1941 & & & & & & & & & & & & & 1 & & & & & & & \\
\hline Arcella conica (Playfair, 1917) & & & & & 1 & & & 1 & 1 & & & & 1 & & & & & & & \\
\hline Arcella costata Ehrenberg, 1847 & & & & & 1 & & & & 1 & & & & 1 & & & & & & & \\
\hline Arcella crenulata Deflandre, 1928 & & & & & & & & & & & & & 1 & & & & & & & \\
\hline Arcella dentata Ehrenberg, 1838 & & & & & 1 & & & & & & & & & & & & & & & \\
\hline Arcella discoides Ehrenberg, 1843 & & & & & 1 & & & & 1 & & & & 1 & & & & & & & \\
\hline $\begin{array}{l}\text { Arcella discoides pseudovulgaris (Deflandre, } \\
\text { 1928) }\end{array}$ & & & & & & & & 1 & 1 & & & & & & & & & & & \\
\hline Arcella gibbosa Pénard, 1890 & & & & & 1 & & & & & & & & 1 & & & & & & & \\
\hline Arcella hemisphaerica Perty, 1852 & & & & & 1 & & & & 1 & & & & 1 & & & & & & & \\
\hline $\begin{array}{l}\text { Arcella hemisphaerica undulata Deflandre, } \\
1928\end{array}$ & & & & & & & & 1 & 1 & & & & & & & & & & & \\
\hline Arcella megastoma Pénard, 1902 & & & & & 1 & & & & 1 & & & & 1 & & & & & & & \\
\hline Arcella mitrata Leidy, 1879 & & & & & & & & & 1 & & & & & & & & & & & \\
\hline Arcella mitrata spectabilis Deflandre, 1928 & & & & & & & & & & & & & 1 & & & & & & & \\
\hline Arcella rota Daday, 1905 & & & & & 1 & & & & 1 & & & & & & & & & & & \\
\hline Arcella rotundata Playfair, 1917 & & & & & & & & & & & & & 1 & & & & & & & \\
\hline Arcella rotundata aplanata Deflandre, 1928 & & & & & 1 & & & & 1 & & & & & & & & & & & \\
\hline Arcella vulgaris Ehrenberg, 1830 & & & & & 1 & & & & 1 & & & & 1 & & & & & & & \\
\hline Arcella vulgaris undulata Deflandre, 1928 & & & & & 1 & & & & 1 & & & & & & & & & & & \\
\hline Arcella vulgaris penardi Deflandre, 1928 & & & & & & & & & & & & & 1 & & & & & & & \\
\hline Arcella sp. & & & & & & & & & & & & & 1 & & & & 1 & 1 & & \\
\hline Família Centropyxidae & & & & & & & & & & & & & & & & & & & & \\
\hline Centropyxis aculeata (Ehrenberg, 1838) & & & & & 1 & & & & 1 & & & & 1 & & & & 1 & & & \\
\hline Centropyxis aerophila Deflandre, 1929 & & & & & 1 & & & & & & & & 1 & & & & & & & \\
\hline Centropyxis arcelloides Pénard, 1902 & & & & & & & & & & & & & 1 & & & & & & & \\
\hline Centropyxis delicatula Pénard, 1902 & & & & & 1 & & & & & & & & & & & & & & & \\
\hline Centropyxis cassis (Wallich, 1864) & & & & & & & & & & & & & 1 & & & & & & & \\
\hline Centropyxis constricta (Ehrenberg, 1841) & & & & & 1 & & & & & & & & 1 & & & & & & & \\
\hline Centropyxis discoides (Pénard, 1890) & & & & & 1 & & & & 1 & & & & 1 & & & & & & & \\
\hline Centropyxis ecornis (Ehrenberg, 1841) & & & & & 1 & & & & & & & & 1 & & & & & & & \\
\hline Centropyxis gibba Deflandre, 1929 & & & & & 1 & & & & 1 & & & & 1 & & & & & & & \\
\hline Centropyxis hirsuta Deflandre, 1929 & & & & & 1 & & & & 1 & & & & 1 & & & & & & & \\
\hline Centropyxis minuta Deflandre, 1929 & & & & & 1 & & & & 1 & & & & 1 & & & & & & & \\
\hline Centropyxis platystoma Pénard, 1890 & & & & & & & & & 1 & & & & 1 & & & & & & & \\
\hline Centropyxis spinosa Cash, 1905 & & & & & 1 & & & & 1 & & & & 1 & & & & & & & \\
\hline
\end{tabular}




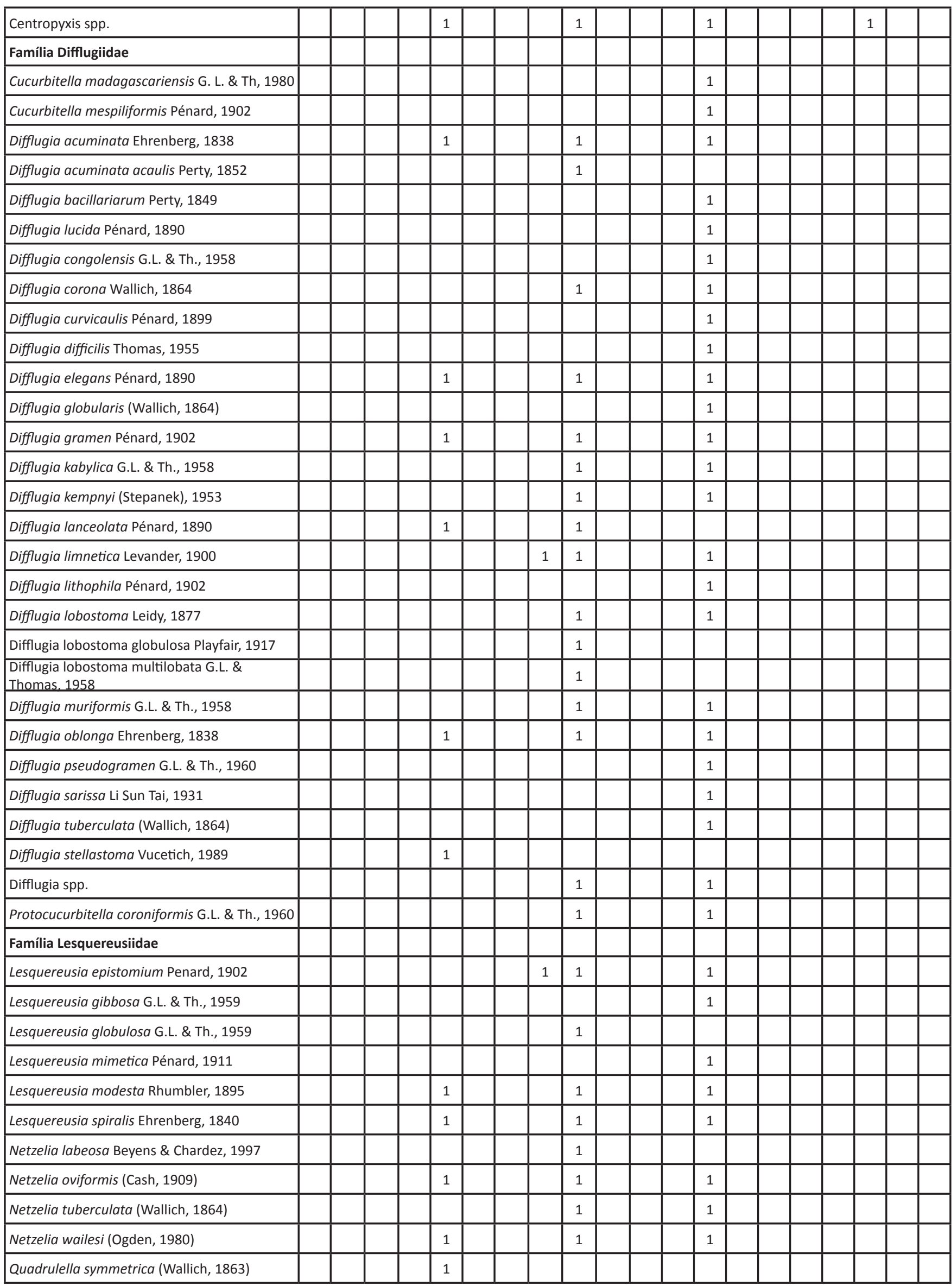




\begin{tabular}{|c|c|c|c|c|c|c|c|c|c|c|c|c|c|c|c|c|c|c|c|c|}
\hline Família Hyalospheniidae & & & & & & & & & & & & & & & & & & & & \\
\hline Nebela sp. & & & & & 1 & & & & & & & & 1 & & & & & & & \\
\hline Difflugiella spp. & & & & & 1 & & & & 1 & & & & & & & & & & & \\
\hline Família Trigonopyxidae & & & & & & & & & & & & & & & & & & & & \\
\hline Cyclopyxis eurystoma (Deflandre, 1929) & & & & & & & & & 1 & & & & & & & & & & & \\
\hline Cyclopyxis kahli (Deflandre, 1929) & & & & & 1 & & & & & & & & & & & & & & & \\
\hline Cyclopyxis sp. & & & & & & & & & & & & & 1 & & & & & & & \\
\hline Família Cyphoderiidae & & & & & & & & & & & & & & & & & & & & \\
\hline Cyphoderia ampulla (Gray, 1873) & & & & & & & & & & & & & 1 & & & & & & & \\
\hline Família Euglyphidae & & & & & & & & & & & & & & & & & & & & \\
\hline Euglypha acanthophora (Ehrenberg, 1841) & & & & & 1 & & & & 1 & & & & 1 & & & & & & & \\
\hline Euglypha brachiata Pénard, 1902 & & & & & 1 & & & & 1 & & & & & & & & & & & \\
\hline Euglypha ciliata (Ehrenberg, 1848) & & & & & & & & & & & & & 1 & & & & & & & \\
\hline Euglypha filifera Pénard, 1890 & & & & & & & & & 1 & & & & 1 & & & & & & & \\
\hline Euglypha laevis (Ehrenberg, 1845) Perty, 1849 & & & & & 1 & & & & 1 & & & & & & & & & & & \\
\hline Euglypha strigosa Ehrenberg, 1871 & & & & & 1 & & & & & & & & & & & & & & & \\
\hline Euglypha tuberculata Dujardin, 1841 & & & & & 1 & & & & & & & & & & & & & & & \\
\hline Família Trinematiidae & & & & & & & & & & & & & & & & & & & & \\
\hline Trinema enchelys (Ehrenberg, 1838) & & & & & 1 & & & & 1 & & & & 1 & & & & & & & \\
\hline Trinema lineare Pénard, 1890 & & & & & & & & & & & & & 1 & & & & & & & \\
\hline Família Phryganellidae & & & & & & & & & & & & & & & & & & & & \\
\hline Phryganella dissimulatoris Chardez, 1969 & & & & & 1 & & & & 1 & & & & & & & & & & & \\
\hline Phryganella hemisphaerica Pénard, 1902 & & & & & & & & & 1 & & & & & & & & & & & \\
\hline Família Pseudodifflugiidae & & & & & & & & & & & & & & & & & & & & \\
\hline Pseudodifflugia sp. & & & & & & & & & & & & & 1 & & & & & & & \\
\hline Família Plagiopyxidae & & & & & & & & & & & & & & & & & & & & \\
\hline Bullinullaria sp. & & & & & & & & & & & & & 1 & & & & & & & \\
\hline Ciliophora & & & & & & & & & & & & & & & & & & & & \\
\hline Família Epistylididae & & & & & & & & & & & & & & & & & & & & \\
\hline Epistylis spp. & & & & & & & & & & & & & 1 & & & & & & & \\
\hline Campanella sp. & & & & & & & & & & & & & 1 & & & & & & & \\
\hline Família Vorticelidae & & & & & & & & & & & & & & & & & & & & \\
\hline Vorticella sp. & & & & & & & & & & & & & 1 & & & & 1 & & & \\
\hline Zoothamnium spp. & & & & & & & & & & & & & 1 & & & & & & & \\
\hline subtotal & 0 & 0 & 0 & 0 & 43 & 0 & 0 & 5 & 53 & 0 & 0 & 0 & 74 & 0 & 0 & 0 & 3 & 2 & 0 & 0 \\
\hline TOTAL & 36 & 64 & 17 & 81 & 172 & 10 & 84 & 68 & 199 & 23 & 70 & 29 & 243 & 36 & 22 & 23 & 78 & 64 & 23 & 34 \\
\hline
\end{tabular}

